Article

\title{
Vegetable Trade Flows and Chain Competitiveness Linkage Analysis Based on Spatial Panel Econometric Modelling and Porter's Diamond Model
}

\author{
Marius Constantin ${ }^{1, *(\mathbb{D})}$, Mihail-Dumitru Sacală ${ }^{2}$ (D), Mihai Dinu ${ }^{1}\left(\mathbb{D}\right.$, Maria Piștalu $^{1}{ }^{1}$, \\ Simona Roxana Pătărlăgeanu ${ }^{1}$ (D) and Irina-Denisa Munteanu ${ }^{2}$ (D)
}

1 Department of Agri-Food and Environmental Economics, Faculty of Agri-Food and Environmental Economics, Bucharest University of Economic Studies, 010374 Bucharest, Romania; mihai.dinu@eam.ase.ro (M.D.); maria.pistalu@eam.ase.ro (M.P.); rpatarlageanu@eam.ase.ro (S.R.P.)

2 Department of Statistics and Econometrics, Faculty of Cybernetics, Statistics and Informatics, Bucharest University of Economic Studies, 010374 Bucharest, Romania; mihai.sacala@csie.ase.ro (M.-D.S.); irinadmunteanu@gmail.com (I.-D.M.)

* Correspondence: marius.constantin@eam.ase.ro

check for updates

Citation: Constantin, M.

Sacală, M.-D.; Dinu, M.; Piștalu, M.; Pătărlăgeanu, S.R.; Munteanu, I.-D. Vegetable Trade Flows and Chain Competitiveness Linkage Analysis Based on Spatial Panel Econometric Modelling and Porter's Diamond Model. Agronomy 2022, 12, 411. https://doi.org/10.3390/ agronomy12020411

Academic Editor: Peter J. Batt

Received: 13 January 2022

Accepted: 4 February 2022

Published: 6 February 2022

Publisher's Note: MDPI stays neutral with regard to jurisdictional claims in published maps and institutional affiliations.

Copyright: (C) 2022 by the authors. Licensee MDPI, Basel, Switzerland. This article is an open access article distributed under the terms and conditions of the Creative Commons Attribution (CC BY) license (https:// creativecommons.org/licenses/by/ $4.0 /)$.

\begin{abstract}
The vegetable sector plays an important role in ensuring food security. Vegetable trade flows in Romania have become a major concern due to constant trade balance deficits despite the country's agricultural potential. Taking into account the paradox between what could be considered an abundance of factor endowments and poor trade balance results, the objective of this research was to study the linkage between vegetable trade flows and chain competitiveness. Spatial panel econometric methods were used to study the impact of the international vegetable market on the demand in Romania, while the Balassa index and Porter's diamond modelling techniques were used to study the competitiveness of the vegetable chain at both county and national levels. By applying the spatial regression method to the international trade and national production panel data, it was found that an increase in the quantity of vegetables imported into Romania would cause an even greater decrease in national vegetable production. The results show that Romanian vegetable production is highly and negatively influenced by the growing appetite for importstherefore leading to a national dependence on the global vegetable chain. Porter's diamond model results confirm that: (a) growing vegetables is profitable in Romania and the average profit margin is higher in this economic sector than in many others; (b) there is a lack of competitiveness caused by the post-communist excessively fragmented agrarian land structure and poor performance of the irrigation, warehousing, and transportation sectors; (c) the national production of vegetables is generally self-sufficient with the exception of three counties that resort to importing and account for more than $70 \%$ of Romania's total vegetable imports; (d) factor endowments cannot be fully harnessed, and this contributes to the deepening of the trade balance deficits. Improvement is possible by fostering competitiveness through increasing the performance of supporting industries and the logistics infrastructure, as well as removing market access barriers for the many small farmers.
\end{abstract}

Keywords: agricultural performance; Balassa index; economic competitiveness; food security; Porter's diamond model; competitive advantage; trade balance; vegetable production

\section{Introduction}

Vegetable consumption is continuously increasing in the EU, while the production of vegetables in Romania has been decreasing [1]. The agricultural sector makes a significant contribution to the Romanian economy, especially when considering its share in the national gross domestic product. Moreover, this industry plays a key role in Romania's international trade and acts as one of the pillars in ensuring food security nationally, as well as in the $\mathrm{EU}$ and other countries. However, there is an urgent need for sectorial convergence in 
the sense of harnessing the national agricultural potential in order to achieve high levels of competitiveness, especially on international markets. Subsistence-based small-scale farming is a common vegetable production pattern that goes hand-in-hand with the lack of competitiveness in the vegetable global value chain, mainly due to the small quantities of vegetables produced nationally [2-4]. Romania's natural resources act as the premise for generating competitiveness in terms of agricultural production, both economically and qualitatively $[5,6]$. If properly taken into account, national production could cover the domestic demand and even allow farmers to obtain additional profit by exporting surplus agri-food products to the international market $[7,8]$. However, the current situation is rather different: the national food market depends on the import of agri-food products, vegetables being no exception $[9,10]$. Even though Romania's cereal production is significant when compared to other players in the global market, the export of raw materials is offset by the growing import of processed foods which have led to a steady increase in Romania's trade deficit for agri-food products.

Regarding food production capabilities, Romania is one of the EU's leading producers of cereals [11,12]. Romania reached a national production peak of 31.5 million tons of cereals in 2018 [13]. As far as the vegetable sector is concerned, the temperate continental climate is beneficial for Romania, which has a variety of factor endowments to facilitate the production of a wide range of vegetables. In 2020, Romania had more than 400,000 hectares in vegetable production [13], and, although the area dedicated to growing vegetables has not significantly decreased during the last decade, the production volumes have decreased at an exacerbated rate. The production of soybeans, early potatoes, autumn potatoes, sugar beet, white cabbage, tomatoes, dried onions, peppers, eggplants, and dried garlic was 4.1 million tons in 2011, which decreased to 3.5 million tons in 2020. On the other hand, the demand for vegetables has increased worldwide during the last decade, with a significant increase in vegetable imports, especially into Romania [14,15].

Generally, vegetables are an important part of the diet for most Romanians, although females tend to consume more than males [16]. The diet of Romanians is rather diverse, and it ensures nutrition security, although low levels of income have been observed in a handful of regions [17], which influences food purchasing behaviors. The Romanian post-communist fragmented agricultural landscape with millions of smallholders has seen the emergence of subsistence agriculture and poor dietary diversity in the rural areas of Romania [18]. In these areas, income is a crucial factor impacting dietary diversification, a factor that constrains the rural population to resort to self-consumption of agricultural products grown on subsistence farms $[19,20]$. Besides the income factor, dietary preferences are also influenced by other factors, such as age, gender, and educational level, as studied by Muresan et al. [21], whose research focused on explaining an increased preference for sustainable food in more wealthy Romanian regions. In the urbanized areas of Romania, the increasing consumption of fast-foods is rapidly becoming a major health issue [22], while rural areas face a completely different type of issue-that of low levels of food affordability and, in some rare cases, even availability [23]. However, the daily calorie intake per capita in Romania has seen a constant increase, and Romanians tend to consume increasing volumes of carbohydrates [24], which also includes vegetables.

Romanian horticulture is a traditional activity of great economic importance $[25,26]$, which has developed over time as a consequence of many favorable natural conditions [27]. However, Romania's chronic trade balance deficits for agri-food products, including vegetables, was demonstrated by research carried out over a ten year span: 2007-2016 [28]. Food security is a complex topic that can be approached from different angles, but one of the most recurrent approaches in the literature is that of agricultural production-as significant volumes of domestic production are crucial to a country's independence from external sources $[29,30]$. It is widely considered that achieving food security objectives is possible by implementing a model of sustainable agricultural production at the level of local communities [31]. Additionally, even though food security has been achieved in Romania, at least in terms of quantity [32], there is room for some components to be 
consolidated in order to improve the food security level, such as: fostering the national production of processed agri-food products instead of selling raw agricultural products. Based on a review of other empirical studies, Table 1 identifies the convergence points of multiple studies on the topic of the international vegetable trade.

Encouraging the production of vegetables at a national level in Romania calls for efficient horticulture, with high levels of competitiveness, in the context of an increasing globalization of agricultural markets $[33,34]$. Stimulating Romanian agricultural exports and international relationships in this sector are just a few efficient methods for spurring national agricultural production and the economic activities in rural areas of Romania. The economic growth generated by agriculture is influenced by international commercial activities, and Romania should pursue it and respond to the requirements of a global agri-food market. The road to agricultural competitiveness, the vegetable chain included, is paved with a healthy commercial policy regarding agri-food products, fully harmonized with the principles of the Common Agricultural Policy and other specific international trade requirements for agri-food products [35,36].

The global exchange of vegetables makes a significant contribution to the added value of the national agri-food value chain, which includes the large, medium, and small vegetable producers. While it is true that such international exchanges can generate profit, it is important not to neglect the requirements for ensuring a high level of food security [37]. Considering both the COVID-19 pandemic, its negative effects on food supply chains, and Romania's competitive advantage, the Romanian government decided to stop exporting cereals outside the European Union, right after the outbreak of the pandemic in the early spring of 2020, in order to ensure high levels of food security [38]. This decision was meant to last for as long as the COVID-19 state of emergency was in force. However, public policies such as these can act as a brake in the face of sustainable development, more specifically, Sustainable Development Goal 1—Zero Hunger [39-41]. 
Table 1. Empirical studies on the international commercial trade in vegetables and their connection with the Romanian context.

\begin{tabular}{|c|c|c|c|c|}
\hline Author(s) \& Publication Year & Method & Findings & Observations & Findings in Relation to the Romanian Context \\
\hline Park and Gachukia, 2021 [42] & $\begin{array}{l}\text { Case study on the export-oriented fresh fruit } \\
\text { and vegetable sector }\end{array}$ & $\begin{array}{l}\text { The authors highlight the essential role of local } \\
\text { institutions, innovation systems, and R\&D in } \\
\text { supporting the local links and their integration in } \\
\text { the vegetable global value chain }\end{array}$ & $\begin{array}{l}\text { This research was focused on the fresh fruit } \\
\text { and vegetable sector in Kenya }\end{array}$ & $\begin{array}{l}\text { Innovation is needed to improve the Romanian } \\
\text { supporting industries and ensure the integration } \\
\text { of small farmers in the vegetable value chain }\end{array}$ \\
\hline Martindale et al., 2020 [44] & $\begin{array}{l}\text { The critical control points method; } \\
\text { multi-indicator methods }\end{array}$ & $\begin{array}{l}\text { All the external resources included in the } \\
\text { production and distribution of foods, including } \\
\text { vegetables, should be re-evaluated from the } \\
\text { perspective of their impact on the final experience } \\
\text { of the consumers, the last chain link }\end{array}$ & $\begin{array}{l}\text { Another topic tackled by this research is the } \\
\text { resilience of the global food supply through } \\
\text { the lens of food security and sustainability }\end{array}$ & $\begin{array}{l}\text { The Romanian vegetable market needs more time } \\
\text { in order for the initial chain links to put the final } \\
\text { experience of consumers at the top of their priority } \\
\text { ranking }\end{array}$ \\
\hline Feyaerts et al., 2020 [45] & Review of empirical evidence & $\begin{array}{l}\text { In the context of the rapid evolution of agri-food } \\
\text { exports in the global value chain, the main } \\
\text { challenge remains to enhance and increase the } \\
\text { efficiency along the links of the local food value } \\
\text { chains }\end{array}$ & $\begin{array}{l}\text { The research was focused on the } \\
\text { relationship between the global and local } \\
\text { food value chains in Africa }\end{array}$ & $\begin{array}{l}\text { The Romanian vegetable value chain demands } \\
\text { more attention in terms of its integration on the } \\
\text { global market }\end{array}$ \\
\hline Wakiyama et al., 2019 [46] & Footprint analysis & $\begin{array}{l}\text { Along the Japanese regional vegetable supply } \\
\text { chains, the vegetables are not delivered to a } \\
\text { market but are instead discarded in the field. This } \\
\text { issue is mitigated by governmental measures } \\
\text { correlated with the relationship between the } \\
\text { regional supply chains and the vegetable global } \\
\text { value chain. }\end{array}$ & $\begin{array}{l}\text { The authors of this research focused on the } \\
\text { regional Japanese agri-food products } \\
\text { supply chains, including vegetables }\end{array}$ & $\begin{array}{l}\text { Food waste is an issue encountered due to high } \\
\text { price volatility during peak harvesting seasons, } \\
\text { which causes a loss of competitiveness. }\end{array}$ \\
\hline von Oppenkowski et al., 2019 [47] & $\begin{array}{l}\text { Correlation of statistical data and national \& } \\
\text { international policies }\end{array}$ & $\begin{array}{l}\text { The Romanian agri-food sector is marked by } \\
\text { subsistence and semi-subsistence farms, and, } \\
\text { because of that, the authors argue that informal } \\
\text { markets must be included in the global agri-food } \\
\text { value chain and the global production networks }\end{array}$ & $\begin{array}{l}\text { The Romanian small farms are in the } \\
\text { spotlight of this research and, in particular, } \\
\text { their lack of contribution to the global } \\
\text { agri-food value chain }\end{array}$ & Not applicable \\
\hline Olaitan et al., 2019 [48] & $\begin{array}{l}\text { A single-case, embedded research design was } \\
\text { applied, with a total of } 26 \text { participants } \\
\text { (including farmers) }\end{array}$ & $\begin{array}{l}\text { The mix of the existing institutional framework, } \\
\text { infrastructure, and logistics issues, on the one side, } \\
\text { and market penetration issues and stakeholders' } \\
\text { incompetence, on the other side, are prominent } \\
\text { barriers that require viable resolutions if } \\
\text { horticultural product exports are to increase }\end{array}$ & $\begin{array}{l}\text { The authors focused on Nigeria's } \\
\text { contribution to the global horticulture } \\
\text { value chains, restricting the research to five } \\
\text { key stakeholder groups situated upstream } \\
\text { in the supply chain }\end{array}$ & $\begin{array}{l}\text { Some areas of Nigeria are facing the same issues } \\
\text { noticed in Romania concerning competitiveness } \\
\text { loss: (a) poor infrastructure and logistics, } \\
\text { (b) market integration issues. }\end{array}$ \\
\hline Vetter et al., 2019 [49] & $\begin{array}{l}\text { A mix of qualitative and quantitative research } \\
\text { methods }\end{array}$ & $\begin{array}{l}\text { Traditional Indonesian food retail appears not to } \\
\text { be in complete demise but rather adaptive and } \\
\text { resilient to its modern competitors in the global } \\
\text { agri-food value chains }\end{array}$ & $\begin{array}{l}\text { This research is specific to Indonesia's } \\
\text { agri-ffood system and its integration in the } \\
\text { global agri-food value chains }\end{array}$ & $\begin{array}{l}\text { Agri-food sector tends to be resilient, but it does } \\
\text { not mean that it is internationally competitive }\end{array}$ \\
\hline Thow and Priyadarshi, 2013 [50] & Qualitative and quantitative methods & $\begin{array}{l}\text { It is possible to design a mechanism for increasing } \\
\text { the supply of fruits and vegetables in developing } \\
\text { countries, contribute to achieving food security, } \\
\text { and to mitigating health issues. }\end{array}$ & $\begin{array}{l}\text { The relationship between the global } \\
\text { vegetable value chain and public health } \\
\text { issues was emphasized. }\end{array}$ & $\begin{array}{l}\text { Ensuring food security is a priority, but the } \\
\text { economic competitiveness of the vegetable sector } \\
\text { should not be neglected }\end{array}$ \\
\hline
\end{tabular}


Table 1. Cont.

Author(s) \& Publication Year

Raab et al., 2013 [51]

A range of qualitative and quantitative mode, and effects analysis

Maertens et al., 2012 [52]

Mix of research methods

Dolan and Humphery, 2004 [53]
Interview, empirical research review, short statistical analysis

\section{Findings}

Responsibilities for preventive consumer

protection constantly change in the case of

international commercial trade in fruits and

vetables, just like any other food chain. As a result, the authors designed a proactive risk and the ent system for the selection of suppliers trade in fruits and vegetables

Increased high-value exports from the horticulture sector and the modernization of export supply chains cause important positive welfare effects on the economy. This can occur in various ways he the effects of the product or the labor market-directly or indirectly

Because of the demand for vegetables, the UK puts a great deal of pressure on the global agri-food value chain. Through its high demand, the UK influences the chain over all its stages, from the way crops are grown to their processing and ownership of the products until they are delivered to regional distribution centers.
The authors concentrated on elaborating an instrument-a proactive risk manage system in the global fruit and vegetable value chains The uniqueness of this study resides in the act that the horticulture export activities in the perspective of warious regional supply chains

This research contributes to the field of international vegetable trade with a unique perspective regarding the governmental actions concerning the trade in fresh vegetables between Africa and the United Kingdom
Findings in Relation to the Romanian Context

Considering the high price volatility in Romania in the case of vegetable production, a risk

management system is needed in order to mitigate the negative effects of the poor performance of the supporting industries and the decoupling of small farmers from the global market

The vegetable sector can contribute more efficiently to the welfare of the Romanian econom if decision-makers adopt strategies designed to support the day-to-day agricultural activities of farmers

Romania should strive to properly integrate small farmers in the global agri-food value chain and production capabilities with UK's demand for vegetables 
Regarding the nexus of national economic competitiveness-vegetable productiontrade balance results in the case of Romania, the literature does not abound with papers tackling this topic, especially not in an econometric manner. In this regard, there is a gap in the literature. However, there are some studies that touch on this subject. For example, Enache [54] constructed a vector autoregressive econometric model to highlight the impact of economic shocks on the import activities of agricultural products, hinting at Romania's lack of competitiveness and risk of becoming dependent on the global agri-food chain. By constructing vector autoregressive and co-integration models, Dinu et al. [55] carried out an econometric study of the causality links between the Romanian imports of agricultural products, on the one hand, and the domestic absorption and exchange rate dynamics, on the other hand, signaling once again policy dysfunctions: Romania has the potential to be competitive in the global agri-food chain by processing raw materials and exporting processed food, but the economic reality shows the opposite. Dragos and Mare [56] used the ordered logit and binary logit econometric models to identify the factors influencing the agricultural insurance policy in Romania, signaling that, among all Romanian agri-food producers, only the vegetable producers were fully aware of the economic importance and necessity of crop insurance. The short-term effects of the COVID-19 pandemic on the agri-food value chains were studied by Ignat and Constantin [57], who noticed significantly more impulsive purchasing behaviors caused by the sanitary crisis and hinted at Romania's dependence on imports in order to meet the national food demand in an economically competitive manner. However, in the context of the Just Transition in the EU [58], trading in agri-food products on the global market calls for more than economic competitiveness: it calls for security and sustainability [59].

This research was aimed at covering the identified gap in the literature regarding the lack of econometric studies of Romania's dependence on international vegetable imports in relation to the national production capabilities. Moreover, the goal was to bring contributions to the literature regarding the linkage between the production, trade balance, and competitiveness. Considering Romania's potential factor endowments in the agri-food industry and its vital role in ensuring food security-not only nationally [15] but also in the EU [60] - it is important to explore the mix of actions that could efficiently contribute to the transformation of Romania's agricultural sector.

Therefore, the main objective of this research was to analyze the commercial flows of fresh vegetables in the case of Romania in relation to local production patterns and identify the reasons why this country with specific factor endowments is lacking competitiveness in the case of the vegetable chain. Thus, an econometric analysis was conducted with respect to the spatial relationship between the variation in Romanian vegetable production and the variation in international commercial flows of vegetables. Afterwards, with respect to the competitiveness of Romanian vegetables chains, Porter's diamond model [61] was adapted to the research data with the purpose of identifying local weaknesses in the chain, as well as at a national level. Lastly, the ultimate goal of these comprehensive analyses was to assist and support finding the best solutions specific to mitigating the negative impact of Romania's international trade flows on vegetable chain competitiveness.

The novelty factor of this research resides in the mix of research methods used to assess the competitiveness of the Romanian vegetable chain in relation to the country's international trade flows-(a) the spatial panel econometric methods were used to study the reactions of the global vegetable market in relation to Romania's market demand; (b) the Balassa index and Porter's diamond model were used to study the competitiveness of the Romanian vegetable chain at county and national levels.

Structured in four sections, this research paper began with Section 1, in which an extensive literature review was developed on the papers regarding the global vegetable chain-approached in various manners and in relation to relevant topics, such as the production and consumption of agri-food products. Section 2 sets the methodological ground for Section 3, which includes the main findings of the research. Finally, the authors 
highlight the conclusions of this study, without overlooking its limitations, which are presented in the Conclusions (Section 4), together with future research directions.

\section{Materials and Methods}

In order to meet the research objectives, import and export data were extracted from Romania's National Institute of Statistics database, TEMPO Online, for the selected period: 2011-2020. In order to observe a broad time interval, the longest period available was selected. Data were collected at county-level and then aggregated. Additionally, at the moment of carrying out this research, most recent data related to the Romanian companies and their financial results corresponding to the fiscal year 2020 were extracted from TopFirme (https:/ / www.topfirme.com/; accessed on 18 January 2022), an online aggregator platform that extracts and processes Romanian Ministry of Public Finance data.

In certain situations, a simple regression model is not enough because of the spatial dependencies between observations, in which case the hypothesis on the independence of errors would not be observed. Lately, the spatial model has been extended towards panel data sets, such models taking into consideration both spatial dependencies and dependence-based errors or dependencies caused by the temporal lag of the chronological series [62]. Authors such as Kapoor et al. [63], Baltagi et al. [64], and Lee and Yu [65] have developed and generalized models that contain dependencies, spatial errors, and fixed or random effects, also proposing a series of tests for choosing the most adequate model for eventual estimates (e.g., the Hausmann test). One of the best-known such models, often used in empirical studies, is the one created by Baltagi and Li [66].

As for the spatial interactions, there are three types that can be taken into consideration [67]. The first one measures the extent to which the dependent variable in unit depends on the dependent variable in unit $j$ ( $j$ being different from $i$ ). This effect is calculated with the help of a spatial weight matrix $W Y_{i t}$, which illustrates the structure of the spatial dependencies among the observations of the endogenous variable. Such a model (SAR) is observed in Equation (1) [68]:

$$
Y_{i t}=\rho W Y_{i t}+X_{i t} \beta+U_{i t}
$$

$\rho$ represents the spatial autoregressive parameter, while $U_{t}$ is another vector measuring the well-behaved disturbances. A second model measures the effect of the correlations among the error terms with the help of a spatial weight matrix $W_{\mu t}$, which illustrates that the units may have similar behavior due to an unnoticed characteristic. Such a SEM model is represented in Equation (2). $\lambda$ represents the intensity of the residual spatial correlation, while $U_{t}$ represents the vector measuring the well-behaved disturbances. A model including both effects, called SARAR, looks like that observed in Equation (3) [67]:

$$
\begin{gathered}
Y_{i t}=X_{i t} \beta+U_{i t}, U_{i t}=\lambda W U_{i t}+\varepsilon_{i t} \\
Y_{i t}=\rho W Y_{i t}+X_{i t} \beta+U_{i t}, U_{i t}=\lambda W U_{i t}+\varepsilon_{i t}
\end{gathered}
$$

The $\rho$ and $\lambda$ parameters measure the power of these spatial dependencies. For panel data, the model includes the fixed or random effects, as in Equation (4) [67].

$$
Y_{i t}=\rho W Y_{i t}+X_{i t} \beta+\mu_{i}+U_{i t}, U_{i t}=\lambda W U_{i t}+\varepsilon_{i t}
$$

$\mu$ is a vector of spatial fixed or random effects.

In order to test which of these dependencies should be included in the regression model, the following tests must be performed: LM test for a spatial lag with $\mathrm{H}_{0}$ : there is no spatial lag dependence of the independent variable (the classical regression model is adequate) and $\mathrm{H}_{1}$ : there is a spatial lag dependence of the independent variable (the spatial regression model is the adequate one); LM robust test for spatial lag and spatial errors with $\mathrm{H}_{0}$ : there are no spatial lag dependencies or spatial errors and $\mathrm{H}_{1}$ : there are spatial lag dependencies or spatial errors. Moreover, in order to use such a model, it is 
necessary to validate it using the following tests: Baltagi, Song, and Koh SLM2 marginal test with $\mathrm{H}_{0}$ : there is no spatial autocorrelation (the classical regression model is adequate) and $\mathrm{H}_{1}$ : random effects; Hausman test for spatial models with $\mathrm{H}_{0}$ : the two models produce similar coefficients and $\mathrm{H}_{1}$ : the two models do not produce similar coefficients (the fixed effects model is the best choice).

After having obtained the test results, the most appropriate model was chosen that could best explain the relationship between the endogenous and exogenous variables and offered an interpretation of the resulting coefficients. Access to these models has increased as new types of software were developed that can be used to perform the necessary tests. The two types of software used in this study were Geoda (dedicated software for spatial econometrics) and the splm package for the R software. They offer an ideal environment due to the already existing tools and infrastructure for panel data analysis. The package for the R software is a comprehensive and important tool in estimating these econometric models by integrating both the spatial components between observations and the ones that appeared between errors, as well as various methods for estimating the regression coefficients [69]. Additionally, both fixed and random effects models can be implemented. The Geoda software helps create the spatial weight matrix, which is then introduced into the $\mathrm{R}$ to create the spatial models [70].

Considering that national vegetable production is measured in physical units (tons) and the imports and exports are measured in thousands of EUR, the physical quantities have been transformed into values by multiplying them by the average product price. At the end, the values were divided by the average exchange rate. The available data extracted from the TEMPO Online database are limited to the following vegetables: soybeans, early potatoes, autumn potatoes, sugar beet, white cabbage, tomatoes, dried onions, peppers, eggplants, and dried garlic.

In order to analyze the relationship between the two variables, production, and import, the $\mathrm{R}$ and Geoda software were used, creating a spatial regression model. The production variable was the dependent one, while the import variable was the one considered independent. Data were studied in the panel-type structure with a view to capturing the individual characteristics, alongside the structural adjustment dynamics. In this way, the efficiency and consistency of the econometric estimates are enhanced. Thus, the observations were divided by the 42 Romanian counties and by several successive periods of time over a 10-year time span (2011-2020). In order to integrate the spatial link between the observations regarding each county into the model, a spatial weight matrix of the queen type was created, which indicates any proximity between observations. Because the model includes spatial coefficients, it was only used to assess the relationship between the two variables of interest and not for making estimates.

Regarding the competitiveness assessment of the Romanian vegetable chain, a countylevel approach ( $N=40$ counties) was adapted to Porter's diamond model [37], with the exception of Bucharest and Ilfov-two Romanian counties with little to no agricultural potential [71-73] yet generators of more than half of Romania's deficit for vegetables. The population densities in these two counties are among the highest of those recorded in Romania [74]. The following variables were included in the model, as explained in Table 2, per Porter's diamond attributes [61]. Data were normalized according to a zero (least favorable) to one (most favorable) scale by reporting the difference between the data at county level and the least favorable situation at a national level to the difference between the most favorable situation and the least favorable one at national level, which made it possible to determine the competitiveness levels between counties based on the four analyzed attributes and variables. 
Table 2. Description of the variables considered in the construction of Porter's diamond model.

\begin{tabular}{|c|c|c|c|}
\hline Porter's Diamond Attributes & Variable Code & Variable Name & Rationale \\
\hline \multirow{3}{*}{ 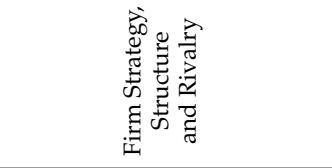 } & C1.1 & $\begin{array}{l}\text { Profit of the companies registered under } \\
\text { 0331 NACE Code }\end{array}$ & \multirow{3}{*}{$\begin{array}{l}\text { The } 0331 \text { NACE code consists of activities dedicated to the } \\
\text { growing of vegetables and melons, roots, and tubers. Values } \\
\text { closer to one signal highly performant Romanian counties based } \\
\text { on the economic and financial results of the companies } \\
\text { growing vegetables. }\end{array}$} \\
\hline & C1.2 & $\begin{array}{c}\text { Profit margin of the companies registered } \\
\text { under } 0331 \text { NACE Code }\end{array}$ & \\
\hline & $\mathrm{C} 1.3$ & Profit per hectare of vegetable crops & \\
\hline \multirow{3}{*}{ 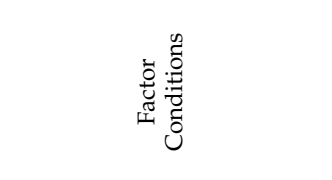 } & $\mathrm{C} 2.1$ & Area cultivated with vegetables & \multirow{3}{*}{$\begin{array}{l}\text { Nowak and Kaminska [75] assessed agricultural } \\
\text { competitiveness in the EU at country level by resorting to many } \\
\text { variables, including agricultural area. The literature is rich in } \\
\text { similar research [76-78]. Moreover, machinery used in } \\
\text { agricultural activities is essential in the assessment of } \\
\text { agricultural competitiveness }[79,80] .\end{array}$} \\
\hline & $\mathrm{C} 2.2$ & $\begin{array}{l}\text { Share of area cultivated with vegetable } \\
\text { from total agricultural area }\end{array}$ & \\
\hline & $\mathrm{C} 2.3$ & $\begin{array}{c}\text { Combines for potato harvesting and other } \\
\text { similar machinery }\end{array}$ & \\
\hline \multirow{3}{*}{ 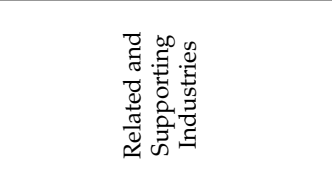 } & C 3.1 & $\begin{array}{l}\text { Profit of the companies registered under } \\
5210 \text { NACE Code }\end{array}$ & \multirow{3}{*}{$\begin{array}{c}\text { The } 5210 \text { NACE code consists of activities dedicated to } \\
\text { warehousing and storage. As studied in Refs. [81-84], storage } \\
\text { facilities, warehousing, and efficient logistics management are } \\
\text { essential for ensuring high levels of economic competitiveness } \\
\text { in the agri-food sector, as well as a performant transportation } \\
\text { infrastructure [85]. }\end{array}$} \\
\hline & C3.2 & $\begin{array}{c}\text { Profit margin of the companies registered } \\
\text { under } 5210 \text { NACE Code }\end{array}$ & \\
\hline & C3.3 & Length of public roads & \\
\hline \multirow{3}{*}{ 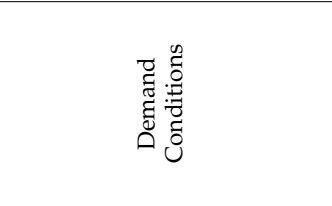 } & C4.1 & Value of imported vegetables & \multirow{3}{*}{$\begin{array}{l}\text { A comprehensive assessment model of agricultural production } \\
\text { also includes evaluating the state of agricultural trade flows } \\
\text { [86,87]. High volumes of deficit signal possible food security } \\
\text { threats [88] and poor agri-food sector resilience [89]. However, } \\
\text { they can also contribute to market development [90]. Regarding } \\
\text { income, it is a variable of great importance in evaluating } \\
\text { demand conditions [91]. }\end{array}$} \\
\hline & C4.2 & $\begin{array}{l}\text { Value of imported vegetables reported to } \\
\text { the value of exported vegetables }\end{array}$ & \\
\hline & C4.3 & Average monthly nominal net earnings & \\
\hline
\end{tabular}

Porter's diamond model represents a framework that facilitates the exploration of the reasons why certain economic sectors within a nation are competitive internationally, as well as the reasons why they are less competitive [92]. The analysis requires data at the level of four attributes that are displayed in the form of a diamond: (1) Firm Strategy, Structure and Rivalry; (2) Factor Conditions; (3) Related and Supporting Industries; and (4) Demand Conditions. The first attribute refers to the national context in which enterprises are active and how different managerial approaches can foster innovation and competitiveness. Domestic rivalry is an essential instrument to ensure international competitiveness, forcing enterprises to develop economically efficient and sustainable business strategies. Factor conditions refer to the natural capital and other types of resources: financial, technological, labor, etc. This diamond attribute puts into the spotlight how different factor endowments contribute to achieving competitiveness internationally. The third diamond attribute is dedicated to the analysis of the foundation on which the focal economic sector within a nation can excel internationally. The fourth diamond attribute considers the rest of the attributes that connect with the market.

With the aim of providing a multidimensional analysis of the competitiveness of the Romanian vegetable sector, the revealed comparative advantage (RCA) was also calculated, as defined by Balassa [93] and explained in Equation (5), by reporting Romania's vegetable export share from Romania's total exports to the world's vegetable export share from total world's exports.

$$
R C A_{i j}=\frac{X_{i j}}{X_{i k}} / \frac{X_{n j}}{X_{n k}}
$$

where: $X$ represents the export value, $i$ represents Romania, $j$ represents the analyzed product/group of agri-products (vegetables in the case of this research), $k$ represents all traded goods, while $n$ represents the world. RCA values greater than one denote an advantageous competitive situation, while an RCA lower than one signals poor comparative advantage. Moreover, the evolution of the Balassa index was studied in this paper.

\section{Results}

\subsection{Spatial Panel Econometric Modelling}

The impact of the Romanian trade balance concerning the vegetable chain in the national trade balance for agri-food products was considerable, especially in 2020, charac- 
terized by a deficit of 391,059 thousand EUR, the fourth-most important source of Romania's trade balance deficit for agri-food products. With respect to the structure of the trade balance deficit in Romania in 2020 in the case of the 24 agri-food product categories as defined in the Combined Nomenclature [94], Figure 1 was elaborated with the aim of showing the most affected agri-food chains in the face of national market demand and current production conditions. Of the 24 categories, half of them, which accounted for almost $90 \%$ of Romania's agri-food trade balance deficit in 2020, were included in Figure 1. Vegetables are at the top of the ranking of deficit sources.

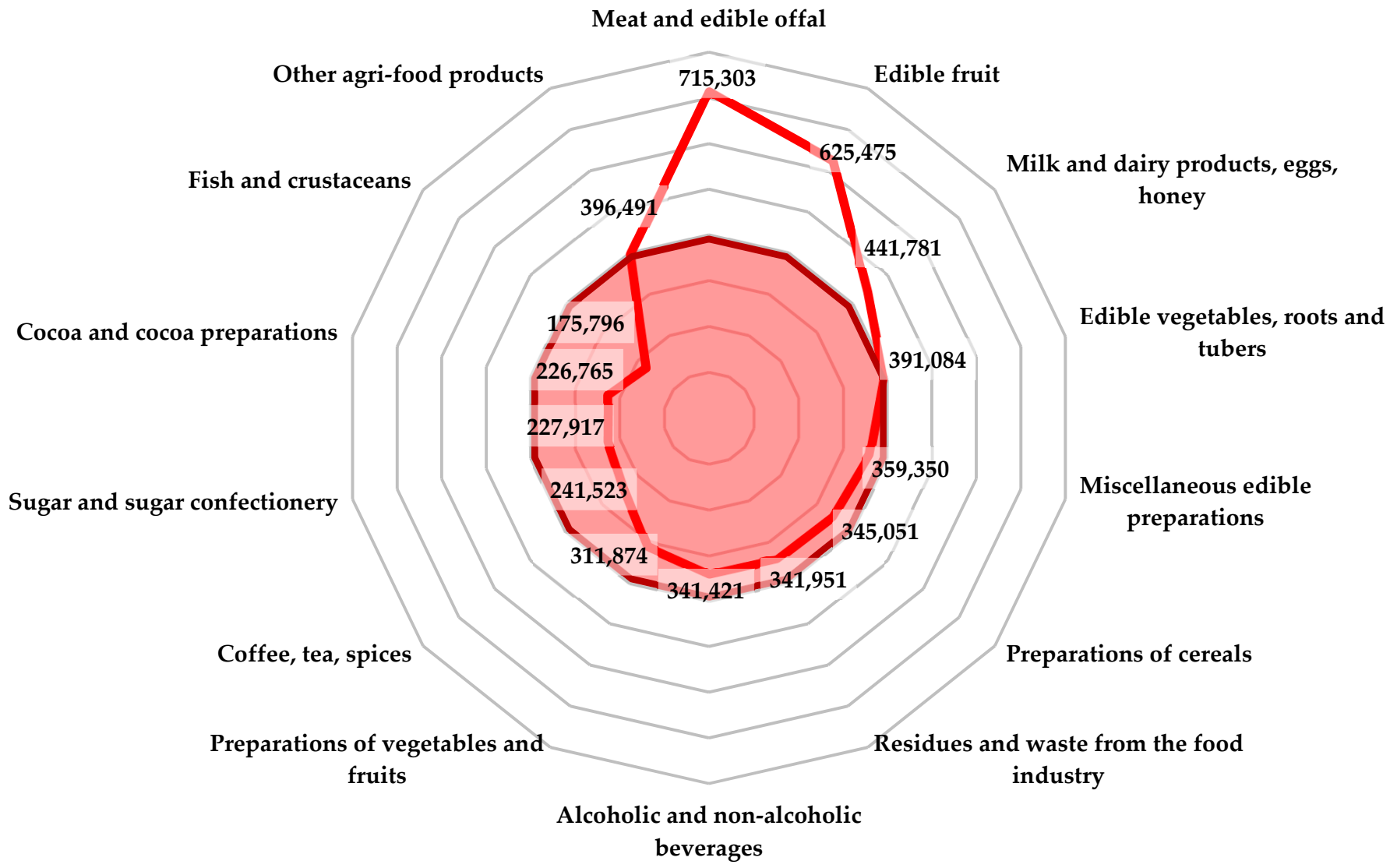

Balance of Trade Deficit Degetable Balance of Trade Deficit

Figure 1. Romania's national agri-food products deficit, expressed in thousand EUR, per agri-food category, in 2020. Source: authors' own graphical representation.

Regarding the national production of vegetables, the most productive Romanian county was Suceava, accounting for $9.1 \%$ of the total production. A visual representation of Romanian national vegetable production was elaborated based on the situation from the year 2020-Figure 2 (the values are measured in thousands EUR). The highest import level was reached in the Bucharest-Ilfov region, which experienced a substantial increase of 4.65 times (2020 reported to 2011), reaching 157,007 thousand EUR in 2020. On the other hand, the highest values of exported vegetables were observed in Bihor County, both in 2011 (12,098 thousand EUR) and in 2020 (24,474 thousand EUR), reaching 26.1\% of the total. The county-level deficits for vegetables can be observed in Figure 3. 


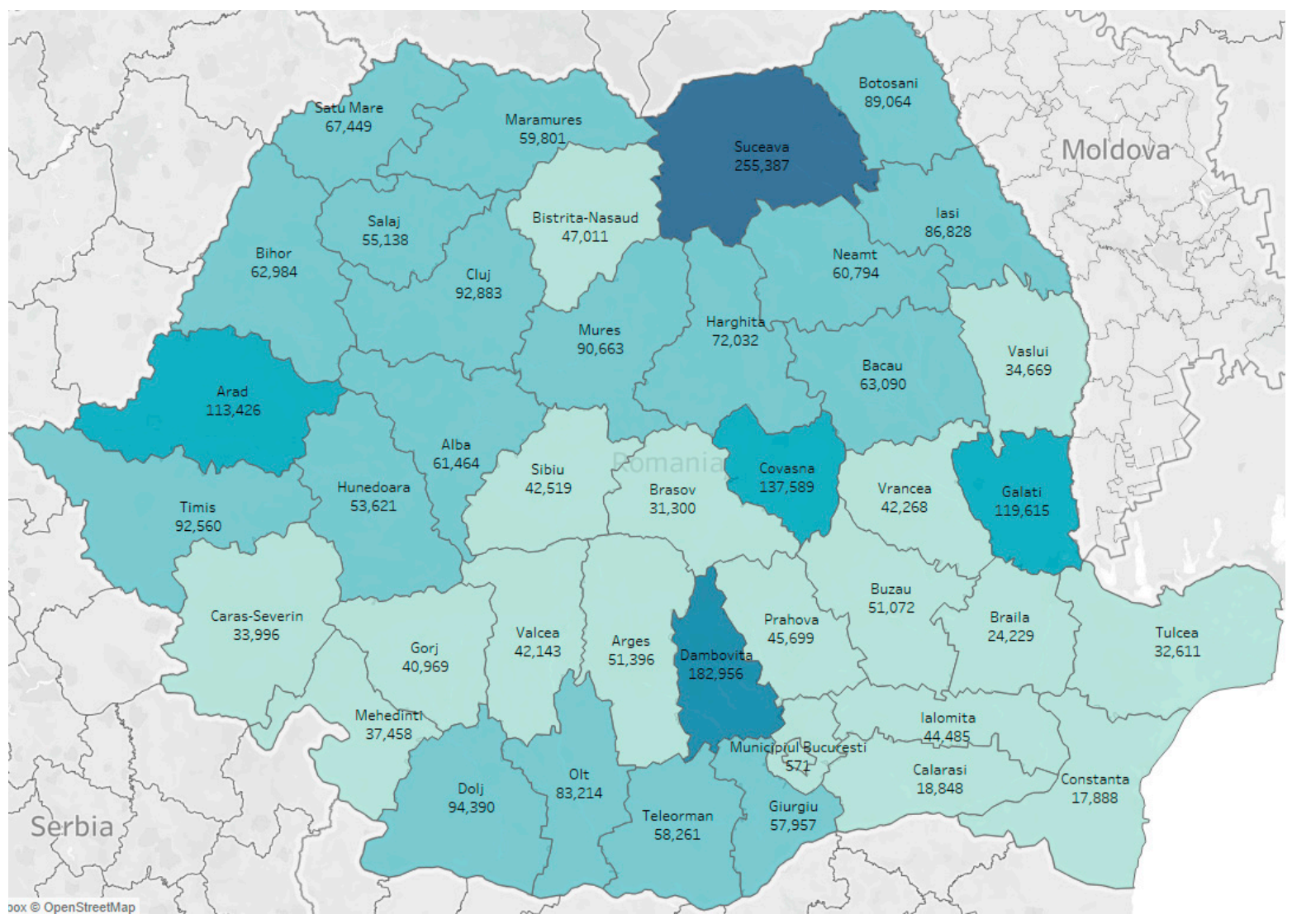

Figure 2. Romania's national vegetable production, per county, in 2020. Source: authors' own graphical representation.

Another significant value besides that of the imports and exports is that of the deficit in the trade balance for vegetables registered in each county. To be more specific, in 2011, the total trade balance deficit for vegetables was 99,187 thousand EUR, whereas, in 2020, this value was four times higher. In both years, the Bucharest-Ilfov region had the largest trade balance deficit for vegetables, especially due to very high volumes and values of vegetable imports, a situation that is similar for each of the years included in the time interval of this study. In all 10 years, the maximum trade balance deficit for vegetables was seen in this region. In the year 2011, the trade balance deficit was worth 71,021 thousand EUR, while, in 2020, it stood at 262,639 thousand EUR, representing $67 \%$ of the total. The situation of the Bucharest-Ilfov region is similar to that of the Prahova and Timis counties. Bucharest, Ilfov, Prahova, and Timis are the four counties most affected by the dependence on vegetable imports, lack of exports, and, inherently, national vegetable production. These Romanian counties act as pressure points on the global vegetable value chain in terms of the Romanian demand. With regard to the production, export, and import of vegetables, the correlation matrix is presented in Table 3 based on county-level data. The correlation matrix indicates that there is a moderate and reverse link between production and imports. Following the spatial dependence and model validation tests, spatial dependence was confirmed, both by the spatial lag and the spatial errors. Thus, the results show that, for both tests, we had to accept the alternative hypothesis with $95 \%$ of the results guaranteed, and the spatial regression model was the appropriate one. The test results can be seen in Table 4. 


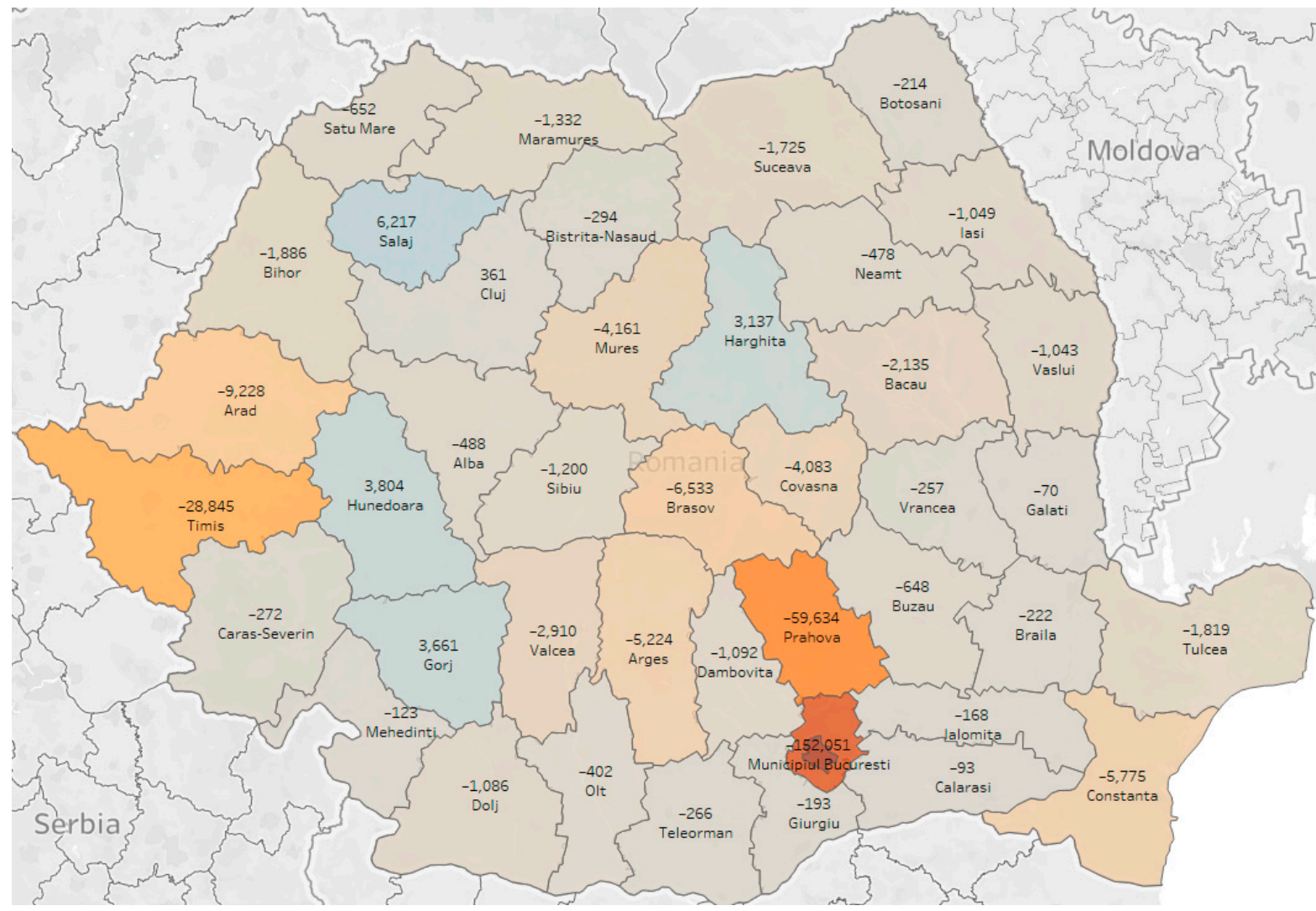

Figure 3. Romania's trade balance deficit for vegetables, per county, in 2020. Source: authors' own graphical representation.

Table 3. Correlation matrix between vegetable production, imports, and exports.

\begin{tabular}{cccc}
\hline & Production & Imports & Exports \\
\hline Production & 1 & -0.19 & -0.10 \\
Imports & -0.19 & 1 & 0.38 \\
Exports & -0.10 & 0.38 & 1 \\
\hline
\end{tabular}

Table 4. Tests for checking the spatial lag dependence. Source: own calculations based on the raw data taken from Ref. [13].

\begin{tabular}{ccc}
\hline Test & Test Value & $p$-Value \\
\hline LM test for spatial lag dependence & 105.01 & $2.2 \mathrm{e}^{-16}$ \\
LM test for spatial error dependence & 103.88 & $2.2 \mathrm{e}^{-16}$ \\
Locally robust LM test for spatial lag and spatial error & 3.9148 & 0.04786 \\
\hline
\end{tabular}

After developing the three spatial regression models for the panel data, the SARAR model, which contains both spatial dependence effects, was validated. The resulting coefficients and their validation can be seen in Table 5 .

The SARAR model is the one validated, and all the parameters are statistically significant. The Baltagi, Song, and Koh tests also indicate the fact that this model has solved the issue of spatial autocorrelation. Thus, the analyzed data show a spatial dependence both between dependent observations and between errors. The coefficient on the spatially correlated errors (lambda) is added as an additional indicator. It has a positive effect, and it is highly significant. As a result, the general model fit is improved. 
Table 5. Model parameters. Source: own calculations based on the raw data taken from Ref. [13].

\begin{tabular}{cccc}
\hline & SAR & SEM & SARAR \\
\hline Vegetables Import & -0.00093286 & -0.058453 & $-0.170650^{\text {a }}$ \\
\hline \multicolumn{4}{c}{ Spatial Parameters } \\
\hline Lambda & Not applicable & $1.20047^{\text {a }}$ & $1.25529^{\text {a }}$ \\
Rho & $0.45306^{\text {a }}$ & Not applicable & $-0.999^{\text {a }}$ \\
\hline${ }^{\text {a Significant for } 0.05 .}$ & &
\end{tabular}

Besides the link between national production and imports, this case study also illustrates the fact that the spatial dependencies among the data are an important aspect that requires an adapted methodology. Otherwise, the results may be compromised. The spatial econometric analysis allows us to state that the production in each county is closely linked to what is happening in the neighboring counties (illustrated by rho coefficient: -0.999) and that the interaction with imports is also triggering a dependence. Considering that the rho coefficient is statistically significant in the SARAR model, an increase in production in a county will determine a decrease in a neighboring county. The model also validates a link between changes in the national vegetable production and imports of this type of agri-food (import coefficient: -0.17 ). Including these spatial dependencies shows that the negative impact of imports over national production is higher, leading to a significant reduction in production if the imported quantity increases. This offers new perspectives regarding the measures that should be adopted in order to encourage and increase the productivity of this nationally important economic sector.

\subsection{Competitiveness Analysis: Balassa Index and Porter's Diamond Model}

From the spatial panel econometric modelling results (Section 3.1) to the Balassa index results (Table 6), Romania's dependency on vegetable imports was noted once more. The Balassa import dynamic index scored a value of 1.14, justifying a loss of competitiveness in the case of the vegetable chain. In this regard, the same unfavorable situation for Romania was also noted in the case of the Balassa export dynamic index (0.84), which proved that, over the course of ten years, Romania lost a part of its export advantage due to: (a) a decrease in the exported vegetables, on the one hand, and (b) aiming to meet the national market demand by resorting more frequently to importing vegetables, on the other hand.

Table 6. Balassa index of export and import with vegetables.

\begin{tabular}{|c|c|c|c|c|c|c|}
\hline & \multicolumn{3}{|c|}{ Export } & \multicolumn{3}{|c|}{ Import } \\
\hline & Year 2011 & Year 2019 & Dynamic Index & Year 2011 & Year 2019 & Dynamic Index \\
\hline Romania-Vegetable share from total & 3.88 & 3.27 & 0.84 & 4.30 & 4.90 & 1.14 \\
\hline World-Vegetable share from total & 2.95 & 2.97 & 1.01 & 3.19 & 3.18 & 1.00 \\
\hline Balassa index & 1.32 & 1.10 & 0.84 & 1.35 & 1.54 & 1.14 \\
\hline
\end{tabular}

As import intensity increased and export intensity decreased, this has caused the loss of national competitiveness in the case of the Romanian vegetable chain. Since three counties (Bucharest, Ilfov, and Prahova) accounted for more than 70\% of the country's vegetable deficit, Romania cannot mitigate its market needs by resorting to national production. Paying more attention to local deficits, Table 7 includes the results of the trade balance with vegetables in the case of each Romanian county, as well as an indicator $\left(I_{i}\right)$-as calculated in Equation (6), which expresses the mean dynamic of the vegetable deficit from one year to another in each Romanian county during the period of analysis.

$$
I_{i}=\sqrt[9]{\prod_{t=2012}^{2020} I_{i t / t-1}}
$$


Table 7. County-level trade balance results with vegetables and the mean dynamic $\left(\mathrm{I}_{\mathrm{i}}\right)$.

\begin{tabular}{|c|c|c|c|}
\hline No. & $\begin{array}{c}\text { Romanian } \\
\text { County }\end{array}$ & $\begin{array}{c}\text { Vegetable Trade Balance Result }{ }^{\text {a }} \\
\text { (Unit of Measurement: Thousand EUR) }\end{array}$ & $\mathbf{I}_{\mathbf{i}} \mathbf{b}$ \\
\hline 1 & Alba & -488 & 1.112 \\
\hline 2 & Arad & -9.228 & -1.608 \\
\hline 3 & Argeș & -5.224 & 1.078 \\
\hline 4 & Bacău & -2.135 & 1.164 \\
\hline 5 & Bihor & -1.886 & -1.033 \\
\hline 6 & Bistrița-Năsaud & -294 & 1.229 \\
\hline 7 & Botoșani & -214 & 1.114 \\
\hline 8 & Brăila & -222 & 0.966 \\
\hline 9 & Brașov & -6.533 & 1.105 \\
\hline 10 & Buzău & -648 & 1.033 \\
\hline 11 & Călărași & -93 & 1.079 \\
\hline 12 & Caraș-Severin & -272 & 1.390 \\
\hline 13 & Cluj & 361 & 1.022 \\
\hline 14 & Constanța & -5.775 & 1.194 \\
\hline 15 & Covasna & -4.083 & 1.077 \\
\hline 16 & Dâmbovița & -1.092 & -1.666 \\
\hline 17 & Dolj & -1.086 & -0.954 \\
\hline 18 & Galați & -70 & -0.900 \\
\hline 19 & Giurgiu & -193 & 0.893 \\
\hline 20 & Gorj & 3.661 & -1.794 \\
\hline 21 & Harghita & 3.137 & -1.261 \\
\hline 22 & Hunedoara & 3.804 & 1.031 \\
\hline 23 & Ialomița & -168 & 1.027 \\
\hline 24 & Iași & -1.049 & 0.999 \\
\hline 25 & Ilfov & $-110,588$ & 1.109 \\
\hline 26 & Maramures & -1.332 & 1.039 \\
\hline 27 & Mehedinți & -123 & 1.048 \\
\hline 28 & București & $-152,051$ & 1.210 \\
\hline 29 & Mureș & -4.161 & 1.049 \\
\hline 30 & Neamt & -478 & 1.133 \\
\hline 31 & Olt & -402 & 1.051 \\
\hline 32 & Prahova & $-59,634$ & 1.368 \\
\hline 33 & Sălaj & 6.217 & -1.511 \\
\hline 34 & Satu Mare & -652 & 1.087 \\
\hline 35 & Sibiu & -1.200 & 1.070 \\
\hline 36 & Suceava & -1.725 & 1.078 \\
\hline 37 & Teleorman & -266 & 1.174 \\
\hline 38 & Timis & $-28,845$ & 1.110 \\
\hline 39 & Tulcea & -1.819 & 1.157 \\
\hline 40 & Vâlcea & -2.910 & 1.154 \\
\hline 41 & Vaslui & -1.043 & -1.370 \\
\hline 42 & Vrancea & -257 & 1.382 \\
\hline
\end{tabular}

a Positive values represent the surplus in the trade balance with vegetables at county-level, while negative values represent the deficit in the trade balance. ${ }^{b}$ This indicator is not significant due to the fact that the trade of balance result reported in the year 2011 has a different sign (i.e., excedent vs. deficit or deficit vs. excedent) reported to the result registered in 2020 .

During the 2011-2020 period, there were seven Romanian counties that suffered transformations at the level of the vegetable trade balance result: from surplus to deficit, which is an unfavorable local and national situation, most specifically in the case of Arad County, with a reported deficit of 9228 thousand EUR in 2020. Out of the 42 Romanian counties, only two of them (Gorj and Sălaj) successfully managed to recover and generate a favorable situation regarding the vegetable trade balance, from deficit to surplus. Thus, in 2020, Gorj recorded a surplus of 3661 thousand EUR, while Sălaj outranked Gorj with 2556 thousand EUR. Regarding the rest of the counties, only three of them registered a decrease in the deficit. For the remaining 30 counties, the deficit increased year by year, therefore marking the signs of vegetable import dependency. Based on the amplitude of 
the deficit, the most significant increase was observed in the case of Prahova County$36.76 \%$ year by year. On top of that, in 2020, the value of the vegetable imports registered by Prahova represented $12.63 \%$ of Romania's total vegetable imports. In the top three net importing counties, together with Ilfov and Bucharest, those three counties accounted for $70 \%$ of Romania's total imports of vegetables. The statistics are similar in the case of the trade balance with respect to Bucharest, Ilfov, and Prahova: they are the main generators of the vegetable trade deficit.

Considering the economic implications of the commercial flows of fresh vegetables in the case of Romania, as well as the country's production patterns, the linkage between competitiveness and factor endowments was analyzed by resorting to Porter's diamond model [61]. In this context, the model was used to assess the competitiveness of the Romanian vegetable chain in relation to the four traditional attributes of the diamond model, as defined by Porter: (a) Firm Strategy, Structure and Rivalry; (b) Factor Conditions; (c) Demand Conditions; (d) Related and Supporting Industries.

With respect to the research methodology (as described in Section 2), the diamond modelling was conducted at a county-level ( $\mathrm{N}=40$ Romanian counties) in accordance with the EU's nomenclature of territorial units. As explained in Section 2, Bucharest and Ilfov counties were excluded from Porter's diamond modelling since these two counties have almost no agricultural potential yet accounted for $55 \%$ of Romania's total vegetable import value in 2020. This situation is a constant caused by many factors, such as: high population density (Bucharest is Romania's capital) [95], higher levels of income [96], the local structure of the economies in Bucharest and Ilfov is significantly different than the ones from the majority of other Romanian counties [97,98] and these two counties do not rely on agricultural activities [99,100], dietary preferences [101], consumer behavior [102], and other factors. Thus, Figure 4 is a graphical representation of Porter's diamond at a national level by averaging the county-level results per research variables, corresponding to the diamond attributes described in Table 2 and quantified in Table 8.

Through Figure 4, Romania's unfavorable situation regarding the competitiveness of the vegetable chain is highlighted. At a national level, the main findings explained per diamond attributes as follows:

- Firm Strategy, Structure and Rivalry: At this level of the economic sector, the concentration of highly profitable Romanian companies involved in growing vegetables showed that most counties are not competitive and that only a handful of them are actually competitive in this agri-food chain. Yet, the national average profit margin for growing vegetables is rather high: $15.7 \%$. From the perspective of the profit margin, despite the success of the active companies in this field, the vegetable sector does not succeed in attracting farmers or entrepreneurs to increase the intensity of the commercial activity. Growing vegetables contributed only $0.05 \%$ to the generation of the turnover registered by Romanian companies in 2020 from all economic sectors.

- Factor Conditions: The analysis of Romania's position with respect to the factors of production is problematic. There were more than 400,000 hectares dedicated to vegetable production in Romania in 2020 - a favorable situation nationally-but land use is different at the county-level and does not favor all Romanian counties. Regarding the machinery used in vegetable growing, the results confirm an uneven distribution of those at the county-level. Other research showed that the machinery is old, often lacking, and only mildly efficient $[103,104]$. On top of that, about half of the cultivated area belongs to subsistence farming, where the production is dedicated to self-consumption [105]. Given that Romania is in the EU top ranking regarding the percentage of subsistence farms [106], the post-communist fragmented agrarian structure acts as a brake in the face of the natural capital endowments.

- Related and Supporting Industries: The poor performance of the storage and transportation industries also has a significant negative impact in not achieving the full potential of the agri-food sector. The lack of efficient infrastructure affects most farmers by 'forcing' them to sell their production immediately after harvesting, when price volatil- 
ity is increased due to the high volumes entering the market [107-109]. Besides the lack of development in these supporting industries, irrigation is another factor that prevents Romania from reaching its full potential in the agri-food sector due to the lack of investments in this regard [110].

- Demand Conditions: What might appear to be a favorable situation regarding market demand is actually not because the 0.66 score recorded by this diamond attribute showed that a significant proportion of Romanian counties do not rely on high volumes of vegetable imports, but those that do cause major deficits at a national level. This result signals potential food security threats and the poor management of factor endowments at a national level. While the averages of A4.1 (0.91) and A4.2 (0.82) scored high values due to the considerable number of observations with minor deficit issues, the average of A4.3 is low (0.26) - therefore signaling that consumer purchasing power is rather weak. This is happening especially in counties with lower deficit volumes. The opposite was observed regarding the top deficit-generating counties: the consumer purchasing power was stronger there. This could partially explain the depth of the deficit.

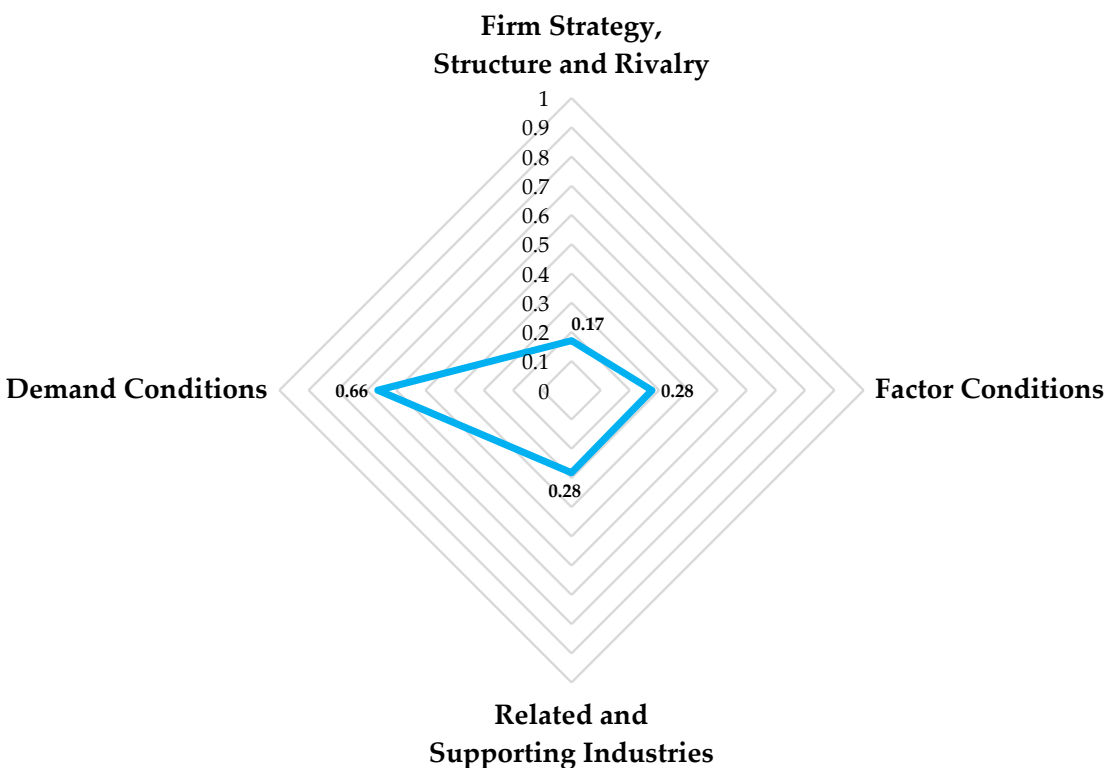

Figure 4. Porter's diamond model applied at the level of Romanian counties-average per diamond attribute. Source: authors' own calculations based on data from Table 8 .

As far as the best performing counties are concerned from the perspective of each of Porter's diamond attributes, the data were graphically represented in Figure 5. Sălaj County is a leader in terms of two attributes-Firm Strategy, Structure and Rivalry and Related Supporting Industries. With respect to the first attribute, Sălaj County makes double the profit compared to the next county and three times the profit per hectare from growing vegetables. On top of that, there is a correlation with the supporting infrastructure for the vegetable chain. In Sălaj County, there is an intense economic activity dedicated to warehousing and storage. As one of the most competitive Romanian counties in terms of vegetable productivity, Sălaj County, has the capabilities to produce and distribute its vegetable production more efficiently than other Romanian counties. However, on the demand side, Sălaj County has a lower import/export ratio and consumers show the signs of weak purchasing power based on their average monthly nominal net earnings. 
Table 8. Porter's diamond model attributes and variable coefficients at county level. Source: authors' own calculations.

\begin{tabular}{|c|c|c|c|c|c|c|c|c|c|c|c|c|c|}
\hline \multirow{2}{*}{ No. } & \multirow{2}{*}{ County } & \multicolumn{3}{|c|}{ Firm Strategy, Structure and Rivalry } & \multicolumn{3}{|c|}{ Factor Conditions } & \multicolumn{3}{|c|}{ Related and Supporting Industries } & \multicolumn{3}{|c|}{ Demand Conditions } \\
\hline & & A1.1 & A1.2 & A1.3 & A2.1 & A2.2 & A2.3 & A3.1 & A3.2 & A3.3 & A4.1 & A4.2 & A4.3 \\
\hline 1 & Sălaj & 1.000 & 0.195 & 1.000 & 0.166 & 0.301 & 0.044 & 0.025 & 1.000 & 0.934 & 0.907 & 0.995 & 0.154 \\
\hline 2 & Galați & 0.488 & 0.372 & 0.180 & 0.669 & 0.684 & 0.014 & 0.049 & 0.184 & 0.552 & 0.947 & 0.981 & 0.259 \\
\hline 3 & Bihor & 0.465 & 0.287 & 0.351 & 0.263 & 0.132 & 0.243 & 0.185 & 0.178 & 0.666 & 0.571 & 0.979 & 0.095 \\
\hline 4 & Covasna & 0.421 & 0.162 & 0.289 & 0.302 & 0.722 & 1.000 & 0.003 & 0.006 & 0.208 & 0.912 & 0.908 & 0.076 \\
\hline 5 & Ialomita & 0.354 & 0.249 & 0.188 & 0.426 & 0.395 & 0.003 & 0.003 & 0.327 & 0.282 & 0.999 & 0.860 & 0.133 \\
\hline 6 & Timis & 0.287 & 0.398 & 0.154 & 0.423 & 0.129 & 0.070 & 0.262 & 0.072 & 0.580 & 0.518 & 0.000 & 0.835 \\
\hline 7 & Bacău & 0.287 & 1.000 & 0.327 & 0.131 & 0.135 & 0.015 & 0.017 & 0.065 & 0.590 & 0.965 & 0.622 & 0.271 \\
\hline 9 & Mures & 0.243 & 0.314 & 0.185 & 0.258 & 0.186 & 0.152 & 0.262 & 0.163 & 0.473 & 0.916 & 0.886 & 0.390 \\
\hline 10 & Cluj & 0.160 & 0.157 & 0.109 & 0.307 & 0.211 & 0.210 & 0.111 & 0.340 & 0.741 & 0.909 & 0.983 & 1.000 \\
\hline 11 & Dâmbovița & 0.140 & 0.112 & 0.054 & 0.624 & 1.000 & 0.991 & 0.005 & 0.277 & 0.880 & 0.977 & 0.922 & 0.193 \\
\hline 12 & Neamț & 0.143 & 0.561 & 0.065 & 0.517 & 0.711 & 0.074 & 0.108 & 0.043 & 0.520 & 0.993 & 0.844 & 0.085 \\
\hline 13 & Olt & 0.129 & 0.281 & 0.054 & 0.567 & 0.438 & 0.002 & 0.011 & 0.173 & 0.752 & 0.995 & 0.683 & 0.302 \\
\hline 14 & Constanța & 0.094 & 0.102 & 0.023 & 1.000 & 0.604 & 0.003 & 1.000 & 0.333 & 0.499 & 0.895 & 0.793 & 0.345 \\
\hline 15 & Tulcea & 0.089 & 0.296 & 0.055 & 0.346 & 0.327 & 0.000 & 0.146 & 0.113 & 0.000 & 0.969 & 0.753 & 0.268 \\
\hline 16 & Gorj & 0.082 & 0.079 & 0.097 & 0.124 & 0.233 & 0.001 & 0.008 & 0.066 & 0.690 & 0.979 & 1.000 & 0.297 \\
\hline 17 & Suceava & 0.080 & 0.132 & 0.021 & 0.920 & 0.991 & 0.607 & 0.089 & 0.352 & 0.580 & 0.955 & 0.943 & 0.129 \\
\hline 19 & Satu Mare & 0.069 & 0.366 & 0.074 & 0.146 & 0.158 & 0.069 & 0.369 & 0.139 & 0.639 & 0.974 & 0.965 & 0.137 \\
\hline 20 & Iași & 0.062 & 0.130 & 0.030 & 0.472 & 0.432 & 0.019 & 0.169 & 0.899 & 0.823 & 0.972 & 0.948 & 0.669 \\
\hline 21 & Brăila & 0.056 & 0.193 & 0.038 & 0.306 & 0.255 & 0.010 & 0.000 & 0.008 & 0.251 & 0.998 & 0.856 & 0.098 \\
\hline 22 & Dolj & 0.053 & 0.043 & 0.013 & 0.963 & 0.543 & 0.013 & 0.111 & 0.113 & 0.473 & 0.968 & 0.953 & 0.384 \\
\hline 23 & Buzău & 0.053 & 0.076 & 0.026 & 0.457 & 0.386 & 0.005 & 0.000 & 0.000 & 0.790 & 0.988 & 0.910 & 0.128 \\
\hline 24 & Prahova & 0.051 & 0.027 & 0.053 & 0.157 & 0.233 & 0.002 & 0.138 & 0.435 & 0.874 & 0.000 & 0.000 & 0.427 \\
\hline 25 & Caraș-Severin & 0.049 & 0.490 & 0.068 & 0.086 & 0.031 & 0.069 & 0.000 & 0.000 & 0.261 & 0.989 & 0.978 & 0.132 \\
\hline 26 & Arad & 0.047 & 0.214 & 0.028 & 0.361 & 0.204 & 0.035 & 0.068 & 0.302 & 0.465 & 0.760 & 0.938 & 0.220 \\
\hline 27 & Hunedoara & 0.040 & 0.291 & 0.032 & 0.237 & 0.327 & 0.493 & 0.029 & 0.040 & 0.908 & 0.978 & 1.000 & 0.106 \\
\hline 28 & Arges & 0.036 & 0.210 & 0.049 & 0.091 & 0.071 & 0.017 & 0.148 & 0.227 & 1.000 & 0.866 & 0.937 & 0.444 \\
\hline
\end{tabular}


Table 8. Cont.

\begin{tabular}{|c|c|c|c|c|c|c|c|c|c|c|c|c|c|}
\hline \multirow{2}{*}{ No. } & \multirow{2}{*}{ County } & \multicolumn{3}{|c|}{ Firm Strategy, Structure and Rivalry } & \multicolumn{3}{|c|}{ Factor Conditions } & \multicolumn{3}{|c|}{ Related and Supporting Industries } & \multicolumn{3}{|c|}{ Demand Conditions } \\
\hline & & A1.1 & A1.2 & A1.3 & A2.1 & A2.2 & A2.3 & A3.1 & A3.2 & A3.3 & A4.1 & A4.2 & A4.3 \\
\hline 29 & Sibiu & 0.036 & 0.268 & 0.058 & 0.057 & 0.060 & 0.320 & 0.003 & 0.035 & 0.417 & 0.979 & 0.847 & 0.541 \\
\hline 30 & Alba & 0.033 & 0.156 & 0.037 & 0.140 & 0.144 & 0.062 & 0.037 & 0.121 & 0.921 & 0.970 & 0.973 & 0.288 \\
\hline 31 & Călărași & 0.024 & 0.372 & 0.016 & 0.303 & 0.214 & 0.006 & 0.051 & 0.369 & 0.294 & 0.996 & 0.890 & 0.227 \\
\hline 32 & Vâlcea & 0.022 & 0.045 & 0.030 & 0.095 & 0.180 & 0.001 & 0.000 & 0.000 & 0.678 & 0.953 & 0.104 & 0.098 \\
\hline 33 & Botoșani & 0.020 & 0.217 & 0.009 & 0.484 & 0.426 & 0.082 & 0.142 & 0.082 & 0.997 & 0.997 & 0.931 & 0.149 \\
\hline 34 & Brașov & 0.016 & 0.105 & 0.038 & 0.000 & 0.000 & 1.004 & 0.085 & 0.130 & 0.406 & 0.880 & 0.801 & 0.498 \\
\hline 35 & Bistrița-Năsăud & 0.013 & 0.443 & 0.015 & 0.140 & 0.173 & 0.134 & 0.008 & 0.046 & 0.390 & 0.989 & 0.966 & 0.044 \\
\hline 36 & Teleorman & 0.011 & 0.060 & 0.004 & 0.546 & 0.346 & 0.021 & 0.112 & 0.044 & 0.307 & 0.997 & 0.778 & 0.044 \\
\hline 37 & Vaslui & 0.009 & 0.317 & 0.010 & 0.139 & 0.080 & 0.002 & 0.000 & 0.000 & 0.715 & 0.984 & 0.625 & 0.151 \\
\hline 38 & Mehedinți & 0.007 & 0.703 & 0.003 & 0.415 & 0.540 & 0.000 & 0.000 & 0.000 & 0.637 & 1.000 & 0.716 & 0.161 \\
\hline 39 & Vrancea & 0.004 & 0.676 & 0.007 & 0.103 & 0.176 & 0.000 & 0.014 & 0.071 & 0.576 & 0.998 & 0.759 & 0.062 \\
\hline 40 & Maramureș & 0.000 & 0.000 & 0.000 & 0.233 & 0.281 & 0.378 & 0.032 & 0.062 & 0.348 & 0.958 & 0.956 & 0.089 \\
\hline
\end{tabular}




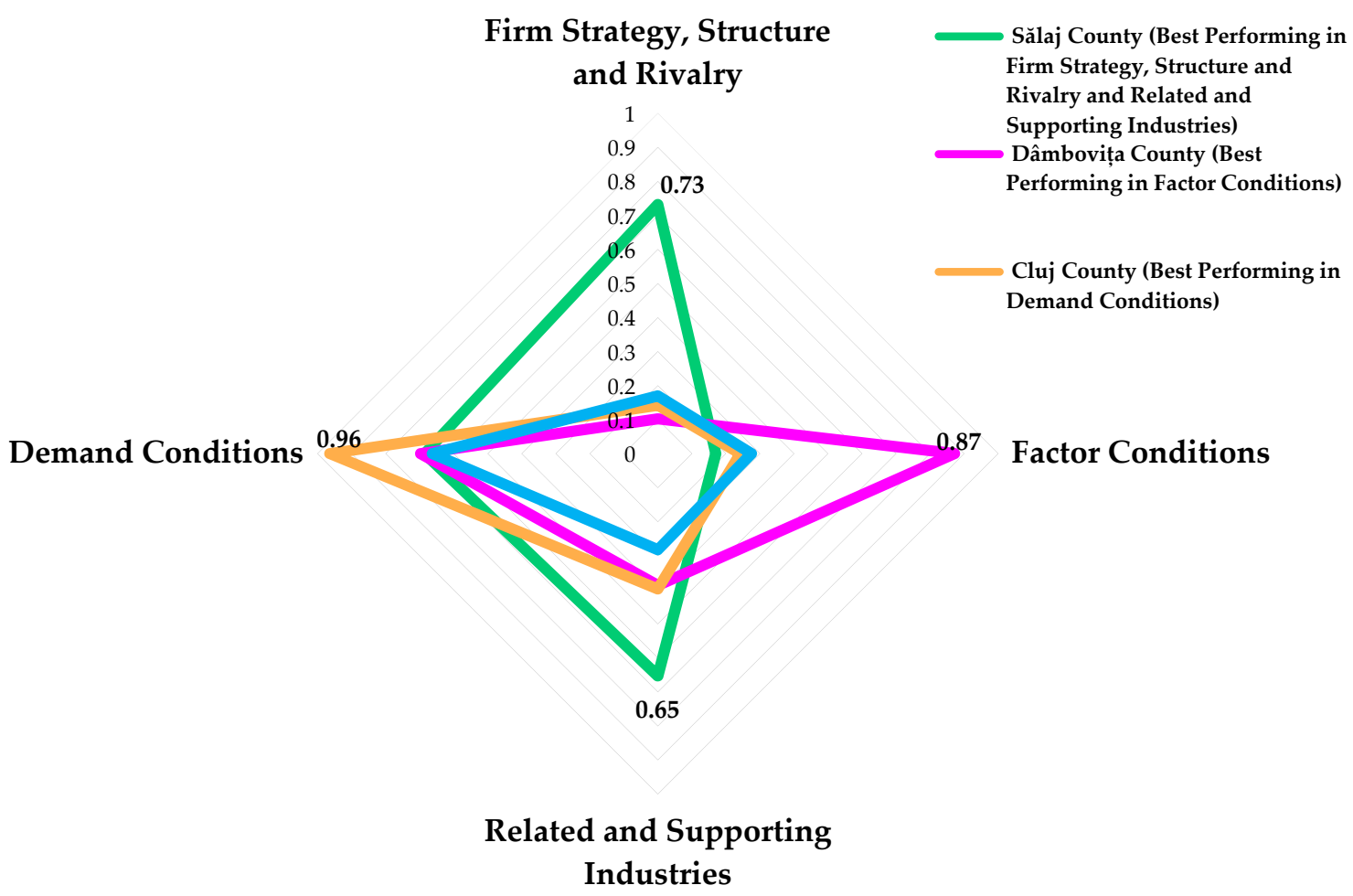

Figure 5. Best-performing Romanian counties in relation to Porter's diamond model attributes. Source: authors' own graphical representation and design based on data from Table 8 .

Another best-performing county is Dâmbovița County based on the Factor Conditions diamond attribute. Even though there are multiple land areas cultivated with vegetables in Dâmbovița County, there is little support from related industries and firms are not competitive when comparing their economic and financial results to those of the companies active in different Romanian counties.

Based on the Demand Conditions diamond attribute, the performance of Cluj County is the best due to a series of reasons: (a) it imports moderate volumes of vegetables; (b) its vegetable import/export ratio is significantly lower than those of other Romanian counties; and (c) the consumer purchasing power is the highest in Cluj County. Besides Cluj, Dâmbovița, and Sălaj Counties, which are the most competitive Romanian counties, as described per Porter's diamond attribute, the least competitive counties in the same regard were graphically represented in Figure 6.

The four least competitive Romanian counties according to Porter's diamond attributes are Maramureș, Argeș, Covasna, and Prahova. These counties registered low scores with respect to two or even three variables. A weak entrepreneurial spirit was noticed in the vegetable sector of Maramures, Arges, Covasna, and Prahova Counties. Regarding the supporting industries-they do not favor the agri-food sector. For example, in Covasna, there are very few companies that are involved in warehousing and storage. Moreover, their profit margin was barely $0.28 \%$, which might not attract entrepreneurs to invest in this direction. Although these four counties are the least competitive based on the research methodology, Covasna County is rich in machineries dedicated to growing vegetables and Arges has the greatest potential to increase its exporting potential.

Since Porter's diamond model demonstrated rather divergent perspectives regarding the Romanian vegetable chain, factor endowments, and trade flows, another element considered relevant to broaden the perspective on competitiveness was the moment of import and export [111,112]. Additionally, horticulture is highly dependent on climate in order to be competitive [113], making it more important to study the relation between vegetable imports and exports monthly-exactly what was done in Figure 7. 


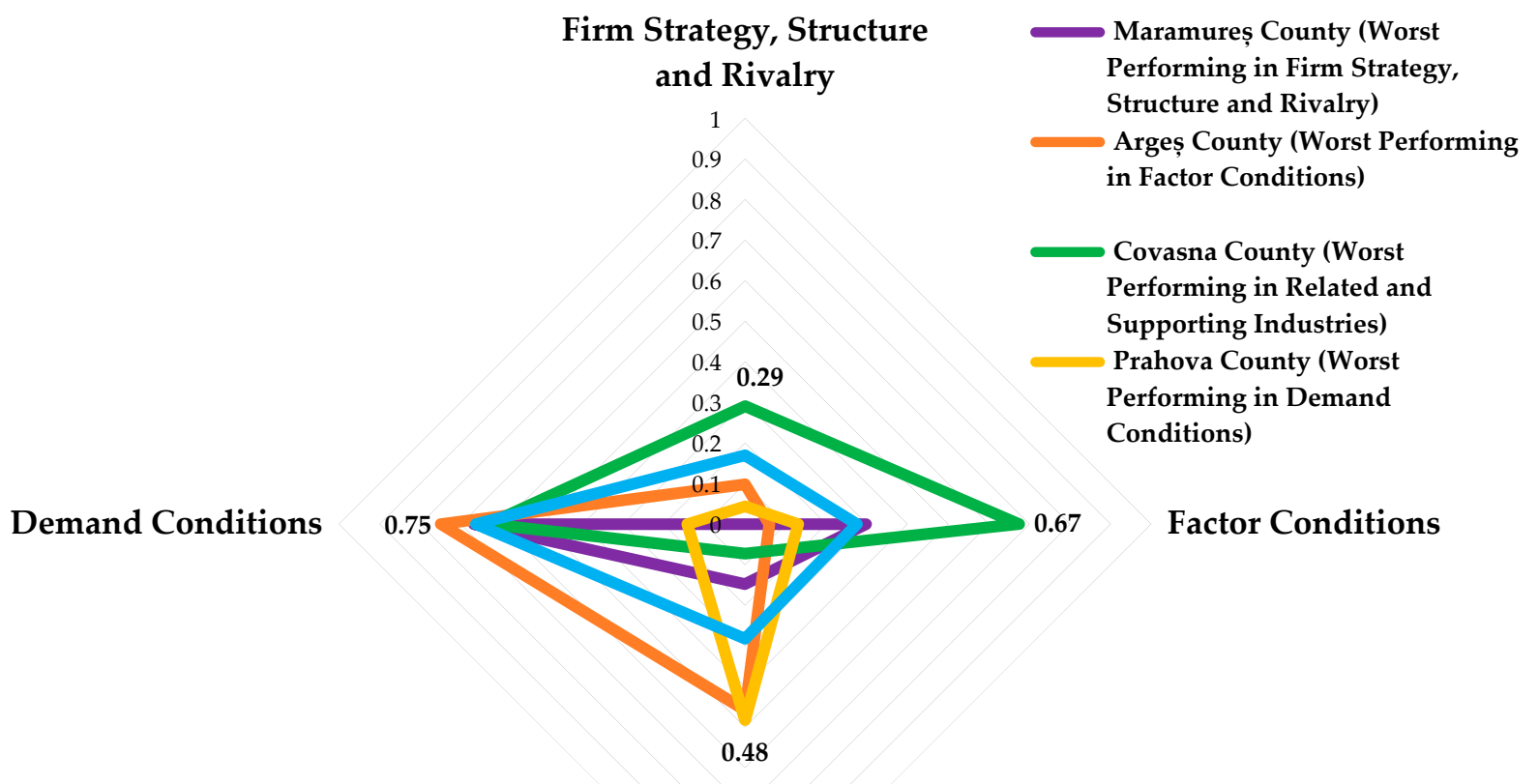

\section{Related and Supporting Industries}

Figure 6. Worst-performing Romanian counties in relation to Porter's diamond model attributes. Source: authors' own graphical representation based on data from Table 8.

The climate of Romania is temperate continental, making it easier to grow vegetables during summer and early autumn. Taking this into consideration, one can notice that when import volumes are high, exports volumes are low and vice versa. The highest values regarding vegetable exports were registered in summer and early autumn, when the vegetable production is intense in Romania. In the same period, starting from May to September, the import volume showed a tendency to decrease because the national demand was covered by national production. The highest import volumes were registered in the winter, highlighting that Romania does not have storage facilities, energy, and irrigation potential to produce vegetables all throughout the year.

These findings support the lack of competitiveness identified based on Porter's diamond model. Romania has some factor endowments, but their full potential is not reached because of major limitations regarding the performance of supporting industries, market access barriers in the case of small farmers [114,115], poor transportation infrastructure, increased price volatility (especially after harvesting), low income from agricultural activities (three times lower than the average [13]), little entrepreneurial interest, and many others. Thus, in order to solve these issues, the following measures and strategic directions are proposed: (i) partially finance the construction of greenhouses and provide energy subsidies to farmers, especially during the cold season, when the import volumes reach the maximum level; (ii) co-finance performing field technologies needed by farmers to boost their productivity; (iii) ensure proper transportation infrastructure and ease of access for farms to sell their products in dedicated local markets instead of them resorting to either self-consumption or throwing products away (i.e., food waste); (iv) improve the legal framework and provide benefits for farms that are associated in cooperatives-highly essential in the context of Romania being a post-communist country where farms still fear joining cooperatives [116]; (v) improve the national vegetable productivity by implementing modern, innovative, and digital technologies in the production of vegetables-as also suggested by Torky and Hassanein [117]; (vi) decision-makers from the public sector should 
collaborate with small farmers and ensure their market integration, at least in the national vegetable value chain [118], if not in the global value chain [119]; and (vii) encourage automation in agriculture with the aim of increasing labor and crop productivity [120].

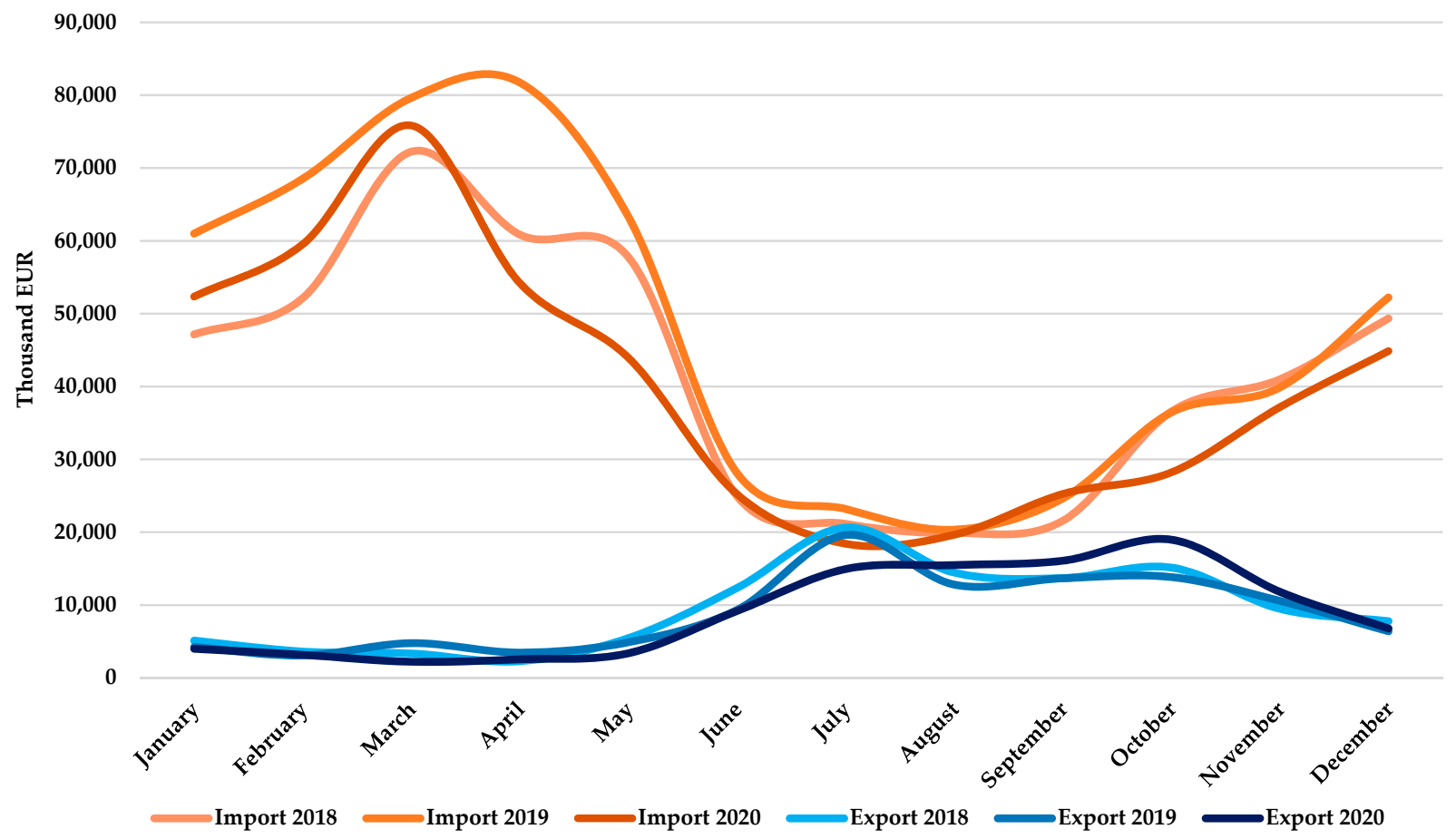

Figure 7. The vegetable Romanian import and export volumes per month. Source: authors' own design.

\section{Conclusions}

Most studies regarding Romania's trade balance deficit with agri-food products point to the same conclusion: with the exception of cereals, Romania is a net importing country with a constantly decreasing level of competitiveness in most agri-food sectors. Taking into consideration the identified literature gap regarding the linkage between vegetable trade flows and chain competitiveness, this research aimed at bringing its contribution to this field by resorting to a mix of research methods to assess the competitiveness of the Romanian vegetable chain in relation to the country's international trade flows for vegetables. Spatial panel econometric methods were used to study the reactions of the global vegetable market in connection with Romania's market demand, while the Balassa index and Porter's diamond model were used to study the competitiveness of the vegetable chain at county and national levels.

The fact that the spatial panel regression model is valid confirms that vegetable imports and national production are structurally correlated at the level of the 42 Romanian counties. The model also validates a relationship between the change in national vegetable production and imports of this agri-food category. Including such spatial dependencies indicated that the negative impact of imports on national production is higher, thus triggering a significant drop in production where the imported quantity increases. This sheds new light on the necessity to consider measures designed to stimulate the national productivity of this sector, as well as its efficient integration into the global vegetable market.

Based on Porter's diamond modelling method, the lack of competitiveness was demonstrated in the case of most Romanian counties from the perspective of the diamond's four attributes: (i) Firm Strategy, Structure and Rivalry; (ii) Factor Conditions; (iii) Related and Supporting Industries; and (iv) Demand Conditions. Taking the selection of variables into account, the following research findings emerged: a significant share of Romanian counties do not rely on high volumes of vegetable imports, but those few that actually do is because they need high volumes of produce in order to meet the local market demand, 
causing major vegetable deficits at a national level, which raises food security concerns. There are very few counties highly efficient in terms of profit generation from growing vegetables, while the rest only take pride in their higher profit margins than those registered by other companies active in completely different economic sectors. Although Romania had more than 400,000 hectares planted with vegetables in 2020, they were mostly used for subsistence farming, and the production was dedicated to self-consumption. Taking these into account, it becomes clear why natural capital endowments cannot be properly harnessed.

The authors acknowledge that this research has limitations, mostly residing in the fact that only three variables were included in each of Porter's diamond model attributes. With more variables integrated into the model, more facets of competitiveness could have been further explored. On the same note, future research avenues include: (i) expanding the Balassa index analysis in relation to the main vegetable exporters with trade flows in Romania-not only in the case of vegetables as a whole but per type of vegetable; (ii) adding more variables in attributes of Porter's diamond model and testing different facets of competitiveness; and (iii) integrating vegetable consumption data into the spatial panel econometric model and studying the production-consumption-trade balance nexus in relation to the competitiveness of the Romanian vegetable chain.

Author Contributions: Conceptualization, all authors; methodology, M.-D.S., I.-D.M. and M.C.; software, M.-D.S. and I.-D.M.; validation, all authors; formal analysis, M.C.; investigation, all authors; resources, all authors; data curation, all authors; writing-original draft preparation, all authors; writing—review and editing, all authors; visualization, M.-D.S., I.-D.M. and M.C.; supervision, S.R.P.; project administration, S.R.P.; funding acquisition, M.C., M.-D.S., M.D., M.P. and S.R.P. All authors have read and agreed to the published version of the manuscript.

Funding: The APC was covered by the authors.

Institutional Review Board Statement: Not applicable.

Informed Consent Statement: Not applicable.

Data Availability Statement: Generally, data used in developing this research are available here: http:/ / statistici.insse.ro:8077/tempo-online/ (Romania's National Institute of Statistics, TEMPO Online database; accessed on 4 January 2022). Data regarding company-specific economic and financial results per NACE codes used in this research are available here: https: / www.topfirme.com/ (TopFirme database; accessed on 18 January 2022).

Acknowledgments: The authors thank the academic editor for the constructive feedback and constant guidance provided during the reviewing process, as well as the three anonymous reviewers for their valuable comments and suggestions. This article is a result of research project "Studiu privind balanța comercială cu produse agroalimentară a României în perioada 2015-2020" (Study on the Romanian Trade Balance with Agri-Food Products during 2015-2020), conducted at the Bucharest University of Economic Studies and financed by REWE Romania.

Conflicts of Interest: The authors declare no conflict of interest.

\section{References}

1. Soare, E.; Dobre, I.; David, L. Economic Analysis in Vegetable Sector of Romania. Scientific Papers Series Management. Econ. Eng. Agric. Rural. Dev. 2016, 16, 333-338.

2. Kostov, P.; Lingard, J. Subsistence farming in transitional economies: Lessons from Bulgaria. J. Rural Stud. 2002, 18, 83-94. [CrossRef]

3. Abele, S.; Frohberg, K. Subsistence Agriculture in Central and Eastern Europe: How to Break the Vicious Circle? Studies on the Agricultural and Food Sector; Institute of Agricultural Development in Transition Economies (IAMO): Halle, Germany, 2004.

4. Mincyte, D. Subsistence and Sustainability in Post-industrial Europe: The Politics of Small-scale Farming in Europeanising Lithuania. Sociol. Rural. 2011, 51, 101-118. [CrossRef]

5. Pawlak, K.; Smutka, L.; Kotyza, P. Agricultural Potential of the EU Countries: How Far Are They from the USA? Agriculture 2021, 11, 282. [CrossRef]

6. Petrescu, D.C.; Petrescu-Mag, R.M. Valuing Land as a Finite and Precious Resource: Citizen Perceptions on Foreign Land Property Safety Limits in Romania. Qual. Access Success 2018, 19 (Suppl. 1), 386-391. 
7. Galli, F.; Grando, S.; Adamsone-Fiskovica, A.; Bjørkhaug, H.; Czekaj, M.; Duckett, D.G.; Almaas, H.; Karanikolas, P.; MorenoPérez, O.M.; Ortiz-Miranda, D.; et al. How do small farms contribute to food and nutrition security? Linking European small farms, strategies and outcomes in territorial food systems. Glob. Food Secur. 2020, 26, 100427. [CrossRef]

8. $\quad$ Brumă, I.S.; Ulman, S.-R.; Cautisanu, C.; Tanasă, L.; Hoha, G.V. Sustainability in the Case of Small Vegetable Farmers: A Matrix Approach. Sustainability 2021, 13, 10320. [CrossRef]

9. Andrei, J.V.; Chivu, L.; Constantin, M.; Subić, J. Economic Aspects of International Agricultural Trade and Possible Threats to Food Security in the EU-27: A Systematic Statistical Approach. In Shifting Patterns of Agricultural Trade: The Protectionism Outbreak and Food Security; Erokhin, V., Tianming, G., Andrei, J.V., Eds.; Springer: Singapore, 2021; pp. 229-261, ISBN 9789811632600. [CrossRef]

10. Stefan, B.; Imre, F. Export competitiveness of the European Union in fruit and vegetable products in the global markets. Agric. Econ. 2016, 62, 299-310. [CrossRef]

11. Popescu, A. Maize and Wheat-Top Agricultural Products Produced, Exported and Imported by Romania. Scientific Papers Series Management. Econ. Eng. Agric. Rural. Dev. 2018, 18, 339-352.

12. Kruzslicika, M. Effects of CAP Measures for Increasing Competitiveness on the Cereal Chain in Romania. Agric. Econ. Rural. Dev. 2019, 16, 91-107.

13. The Romanian National Institute for Statistics. The Romanian National Institute for Statistics Database, TEMPO Online; INS: Bucharest, Romania, 2022. Available online: http:/ / statistici.insse.ro:8077/tempo-online/\#/pages/tables/insse-table (accessed on 4 January 2022).

14. Dias, J.S.; Ortiz, R. New Strategies and Approaches for Improving Vegetable Cultivars. In The Basics of Human Civilization; CRC Press: London, UK, 2021; pp. 349-381. [CrossRef]

15. Pătărlăgeanu, S.R.; Miclea, A.; Sacală, M.-D.; Teodor, C.; Dinu, M.; Piștalu, M.; Constantin, M.; Lazăr, V. Study on the Romanian Trade Balance with Agri-Food Products during 2015-2020; Editura ASE: Bucharest, Romania, 2020; ISBN 978-606-34-0355-2. Available online: https:/ / www.ceeol.com/search/book-detail?id=917212 (accessed on 1 December 2021).

16. Ladaru, G.-R.; Ilie, D.; Diaconeasa, M.; Petre, I.; Marin, F.; Lazar, V. Influencing Factors of a Sustainable Vegetable Choice. The Romanian Consumers' Case. Sustainability 2020, 12, 9991. [CrossRef]

17. Luca, L.; Alexandri, C.; Păuna, B. Demand for Food Diversity in Romania. Available online: https://www.igi-global.com/ chapter/demand-for-food-diversity-in-romania/www.igi-global.com/chapter/demand-for-food-diversity-in-romania/2329 89 (accessed on 31 January 2022).

18. Varga, M. Resistant to change? Smallholder response to World Bank-sponsored "commercialisation" in Romania and Ukraine. Can. J. Dev. Stud. 2019, 40, 528-545. [CrossRef]

19. Tudor, M.M. The Role of Small-Scale Agriculture in Romanian Context. In Proceedings of the Agrarian Economy and Rural Development-Realities and Perspectives for Romania, 6th Edition of the International Symposiumm, Bucharest, Romania, 15 November 2015; pp. 279-285.

20. Ion, R.A. The Influence of People Income on Vegetables Consumption in Romania. In Proceedings of the Agrarian Economy and Rural Development-Realities and Perspectives for Romania, 9th Edition of the International Symposium, Bucharest, Romania, 18 November 2018; pp. 298-302.

21. Muresan, I.C.; Harun, R.; Arion, F.H.; Brata, A.M.; Chereches, I.A.; Chiciudean, G.O.; Dumitras, D.E.; Oroian, C.F.; Tirpe, O.P. Consumers' Attitude towards Sustainable Food Consumption during the COVID-19 Pandemic in Romania. Agriculture 2021, 11, 1050. [CrossRef]

22. Bîlbîie, A.; Druică, E.; Dumitrescu, R.; Aducovschi, D.; Sakizlian, R.; Sakizlian, M. Determinants of Fast-Food Consumption in Romania: An Application of the Theory of Planned Behavior. Foods 2021, 10, 1877. [CrossRef] [PubMed]

23. Bacârea, A.; Bacârea, V.; Cînpeanu, C.; Teodorescu, C.; Seni, A.; Guiné, R.; Tarcea, M. Demographic, Anthropometric and Food Behavior Data towards Healthy Eating in Romania. Foods 2021, 10, 487. [CrossRef]

24. Nica, M.; Petre, I.L. Nutritional Security in Romania. In Proceedings of the 1st International Conference on Economics and Social Sciences, Bucharest, Romania, 16-17 April 2018; pp. 68-74.

25. Grigoras, M.A. Trends in Romania's Agricultural Production; Scientific Papers Series. Manag. Econ. Eng. Agric. Rural. Dev. 2016, $16,183-192$.

26. Burghelea, C.; Bălan, M.; Volintiru, A.M.; Aceleanu, M.I. Trend in Producer Prices for Agricultural Products in Romania and EU. In Proceedings of the 25th International Business Information Management Association Conference-Innovation Vision 2020: From Regional Development Sustainability to Global Economic Growth, Amsterdam, The Netherlands, 7-8 May 2015; pp. 9-17.

27. Lato, K.; Popa, M.; Lato, A.; Corches, M.; Radulov, I.; Berbecea, A.; Crista, F. Economic Efficiency of Main Soil Types from West Region of Romania for Various Agricultural Crops. J. Environ. Prot. Ecol. 2019, 20, 1022-1028.

28. Andrei, J.V.; Popescu, G.H.; Nica, E.; Chivu, L. The impact of agricultural performance on foreign trade concentration and competitiveness: Empirical evidence from Romanian agriculture. J. Bus. Econ. Manag. 2020, 21, 317-343. [CrossRef]

29. Tolmachev, M.; Tsypin, A.; Barashov, N. Statistical Study of Dynamics of the Agricultural Production of Post-Soviet Countries in the Context of Food Security. In Proceedings of the International Science and Technology Conference "FarEastCon 2019", Vladivostok, Russia, 1-4 October 2019; pp. 699-711. [CrossRef] 
30. Chivu, L.; Constantin, M.; Privitera, D.; Andrei, J.V. Land Grabbing, Land Use, and Food Export Competitiveness: Bibliometric Study of a Paradigm Shift. In Shifting Patterns of Agricultural Trade: The Protectionism Outbreak and Food Security; Erokhin, V., Tianming, G., Andrei, J.V., Eds.; Springer: Singapore, 2021; pp. 143-164. [CrossRef]

31. Pătărlăgeanu, S.R.; Constantin, M.; Strat, G.; Deaconu, M.E. Best Practices of Circular Activities in the Agri-Food Sector from the Netherlands and Romania; ASE Publishing House: Bucharest, Romania, 2021; ISBN 978-606-34-0375-0. Available online: https: / / www.ceeol.com/search/book-detail?id=949510 (accessed on 4 January 2022).

32. Istudor, N.; Ion, R.A.; Sponte, M.; Petrescu, I.E. Food Security in Romania-A Modern Approach for Developing Sustainable Agriculture. Sustainability 2014, 6, 8796-8807. [CrossRef]

33. Jerzak, M.A.; Śmiglak-Krajewska, M. Globalization of the Market for Vegetable Protein Feed and Its Impact on Sustainable Agricultural Development and Food Security in EU Countries Illustrated by the Example of Poland. Sustainability 2020, 12, 888. [CrossRef]

34. Chiripuci, B.; Todirica, I.; Toderasc, A. The Impact of Globalization Phenomena on Food Safety. In Proceedings of the International Conference on Economics and Social Sciences, Bucharest University of Economic Studies, Bucharest, Romania, 16-17 April 2018; Volume 1, pp. 21-27.

35. Teimoury, E.; Nedaei, H.; Ansari, S.; Sabbaghi, M. A multi-objective analysis for import quota policy making in a perishable fruit and vegetable supply chain: A system dynamics approach. Comput. Electron. Agric. 2013, 93, 37-45. [CrossRef]

36. Gramzow, A.; Batt, P.J.; Afari-Sefa, V.; Petrick, M.; Roothaert, R. Linking smallholder vegetable producers to markets-A comparison of a vegetable producer group and a contract-farming arrangement in the Lushoto District of Tanzania. J. Rural Stud. 2018, 63, 168-179. [CrossRef]

37. Kruse, H. Food safety in an international perspective. J. Consum. Prot. Food Saf. 2015, 10, 105-107. [CrossRef]

38. Bloomberg. Food Supply Fears Are Growing as Romania Bans Grain Export; Bloomberg: New York, NY, USA, 2020.

39. Navarro-Pabsdorf, R.M.; Martínez-Alcalá, C.; Moral-Pajares, E. Can International Trade Help Africa's Least Developed Countries Achieve SDG-1? Sustainability 2020, 12, 4470. [CrossRef]

40. Xu, Z.; Li, Y.; Chau, S.N.; Dietz, T.; Li, C.; Wan, L.; Zhang, J.; Zhang, L.; Li, Y.; Chung, M.G.; et al. Impacts of international trade on global sustainable development. Nat. Sustain. 2020, 3, 964-971. [CrossRef]

41. Scown, M.W.; Nicholas, K.A. European agricultural policy requires a stronger performance framework to achieve the Sustainable Development Goals. Glob. Sustain. 2020, 3, e11. [CrossRef]

42. Park, E.; Gachukia, M.K. The Role of the Local Innovation System for Inclusive Upgrading in the Global Value Chain: The Case of KenyaGAP in the Kenyan Horticultural Sector. Eur. J. Dev. Res. 2020, 33, 578-603. [CrossRef]

43. Tyce, M. A 'Private-sector Success Story'? Uncovering the Role of Politics and the State in Kenya's Horticultural Export Sector. J. Dev. Stud. 2020, 56, 1877-1893. [CrossRef]

44. Martindale, W.; Swainson, M.; Choudhary, S. The Impact of Resource and Nutritional Resilience on the Global Food Supply System. Sustainability 2020, 12, 751. [CrossRef]

45. Feyaerts, H.; Broeck, G.V.D.; Maertens, M. Global and local food value chains in Africa: A review. Agric. Econ. 2019, 51, 143-157. [CrossRef]

46. Wakiyama, T.; Lenzen, M.; Faturay, F.; Geschke, A.; Malik, A.; Fry, J.; Nansai, K. Responsibility for food loss from a regional supply-chain perspective. Resour. Conserv. Recycl. 2019, 146, 373-383. [CrossRef]

47. Von Oppenkowski, M.; Hassler, M.; Roesler, T. Informal markets and global value chains—The disembedding of Romanian dairy smallholders. Eur. Plan. Stud. 2019, 27, 995-1012. [CrossRef]

48. Olaitan, O.F.; Hubbard, N.; Bamford, C.G. The potential for the participation of Nigeria in global horticulture value chains. Int. J. Emerg. Mark. 2019, 15, 93-110. [CrossRef]

49. Vetter, T.; Larsen, M.N.; Bruun, T.B. Supermarket-Led Development and the Neglect of Traditional Food Value Chains: Reflections on Indonesia's Agri-Food System Transformation. Sustainability 2019, 11, 498. [CrossRef]

50. Thow, A.M.; Priyadarshi, S. Aid for Trade: An opportunity to increase fruit and vegetable supply. Bull. World Heal. Organ. 2012, 91, 57-63. [CrossRef]

51. Raab, V.; O’Hagan, J.; Stecher, F.; Fürtjes, M.; Brugger, A.; Bratzler, M.; Wibbe, B.; Petersen, B. A preventive approach to risk management in global fruit and vegetable supply chains. WIT Trans. Ecol. Environ. 2013, 170, 147-158. [CrossRef]

52. Maertens, M.; Minten, B.; Swinnen, J. Modern Food Supply Chains and Development: Evidence from Horticulture Export Sectors in Sub-Saharan Africa. Dev. Policy Rev. 2012, 30, 473-497. [CrossRef]

53. Dolan, C.; Humphrey, J. Changing Governance Patterns in the Trade in Fresh Vegetables between Africa and the United Kingdom. Environ. Plan. A Econ. Space 2004, 36, 491-509. [CrossRef]

54. Enache, C. An Econometric Analysis of Romania's Agricultural Foreign Trade with Developing Countries. J. East. Eur. Res. Bus. Econ. 2015, 2015, 1-11. [CrossRef]

55. Dinu, T.; Enache, C.; Condei, R.; Niculae, I.; Stoian, E. Romania's Foreign Trade in Agricultural Products Measurement Methods and Techniques. J. East. Eur. Res. Bus. Econ. 2015, 1-11. [CrossRef]

56. Dragos, S.L.; Mare, C. An econometric approach to factors affecting crop insurance in Romania. E+M Èkon. Manag. 2014, 17, 93-103. [CrossRef] 
57. Ignat, R.; Constantin, M. Short-Term Effects of COVID-19 Pandemic on Agri-Food Value Chains in Romania. In Proceedings of the 3rd International Conference on Economics and Social Sciences, Bucharest, Romania, 15-16 October 2020; pp. 578-588. [CrossRef]

58. Voicu-Dorobanțu, R.; Volintiru, C.; Popescu, M.-F.; Nerău, V.; Stefan, G. Tackling Complexity of the Just Transition in the EU: Evidence from Romania. Energies 2021, 14, 1509. [CrossRef]

59. Chevallier-Chantepie, A.; Batt, P.J. Sustainable Purchasing of Fresh Food by Restaurants and Cafes in France. Agronomy 2021, 11, 2357. [CrossRef]

60. Dragoi, M.C.; Andrei, J.V.; Mieila, M.; Panait, M.; Dobrota, C.E.; Ladaru, R. Food Safety and Security in Romania-An Econometric Analysis in the Context of National Agricultural Paradigm Transformation. Amfiteatru Econ. 2018, 20, 134-150. [CrossRef]

61. Porter, M. Competitive Advantage of Nations; Macmillan: New York, NY, USA, 1990.

62. Salima, B.A.; Julie, L.G.; Lionel, V. Spatial Econometrics on Panel Data. In Handbook of Spatial Analysis: Theory and Practical Application with R; Institut National de la Statistique et des Études Économiques: Paris, France, 2018; pp. 179-203.

63. Kapoor, M.; Kelejian, H.H.; Prucha, I.R. Panel data models with spatially correlated error components. J. Econ. 2007, 140, 97-130. [CrossRef]

64. Baltagi, B.H.; Bresson, G.; Pirotte, A. Panel unit root tests and spatial dependence. J. Appl. Econ. 2007, 22, 339-360. [CrossRef]

65. Lee, L.-F.; Yu, J. Some recent developments in spatial panel data models. Reg. Sci. Urban Econ. 2010, 40, 255-271. [CrossRef]

66. Baltagi, B.H.; Li, D. Prediction in the Panel Data Model with Spatial Correlation. Adv. Spat. Econom. 2004, 283-295. [CrossRef]

67. Elhorst, J.P. Spatial Panel Data Analysis. Encycl. GIS 2017, 2050-2058. [CrossRef]

68. Debarsy, N.; Ertur, C. Testing for spatial autocorrelation in a fixed effects panel data model. Reg. Sci. Urban Econ. 2010, 40, 453-470. [CrossRef]

69. Millo, G.; Piras, G. splm: Spatial Panel Data Models inR. J. Stat. Softw. 2012, 47, 1-38. [CrossRef]

70. Anselin, L.; Syabri, I.; Kho, Y. GeoDa: An Introduction to Spatial Data Analysis. In Handbook of Applied Spatial Analysis; Springer: Berlin/Heidelberg, Germany, 2009; pp. 73-89. [CrossRef]

71. Ciutacu, C.; Chivu, L.; Andrei, J.V. Similarities and dissimilarities between the EU agricultural and rural development model and Romanian agriculture. Challenges and perspectives. Land Use Policy 2015, 44, 169-176. [CrossRef]

72. Chivu, L.; Andrei, J.V.; Zaharia, M.; Gogonea, R.-M. A regional agricultural efficiency convergence assessment in RomaniaAppraising differences and understanding potentials. Land Use Policy 2020, 99, 104838. [CrossRef]

73. Gavrilescu, C. The Romanian Agri-Food Trade: In a Permanent Deficit? An Analysis of the Last Two Decades. In Proceedings of the Agrarian Economy and Rural Development-Realities and Perspectives for Romania, 9th Edition of the International Symposium, Bucharest, Romania, 15 November 2018; The Research Institute for Agricultural Economy and Rural Development (ICEADR): Bucharest, Romania, 2018; pp. 16-22.

74. Stoicescu, A.; Alecu, I.N.; Tudor, V. Demographic Analysis of Bucharest-Ilfov Region. Procedia Econ. Finance 2013, 6, 392-398. [CrossRef]

75. Anna, N.; Agnieszka, K. Agricultural competitiveness: The case of the European Union countries. Agric. Econ. 2016, 62, 507-516. [CrossRef]

76. Delgado, M.; Ketels, C.; Porter, M.E.; Stern, S. The Determinants of National Competitiveness; Working Paper Series; National Bureau of Economic Research: Cambridge, MA, USA, 2012. [CrossRef]

77. Jambor, A.; Babu, S. Understanding the Factors Behind Agricultural Competitiveness. Compet. Glob. Agric. 2016, 131-149. [CrossRef]

78. Hochuli, A.; Hochuli, J.; Schmid, D. Competitiveness of diversification strategies in agricultural dairy farms: Empirical findings for rural regions in Switzerland. J. Rural Stud. 2021, 82, 98-106. [CrossRef]

79. Zhao, L. Determinants of Food Industry Competitiveness in China from the Perspectives of Porter's Diamond Model. In Proceedings of the 3rd International Conference on Judicial, Administrative and Humanitarian Problems of State Structures and Economic Subjects (JAHP 2018), Domodedovo, Russia, 1-4 April 2018; Atlantis Press: Paris, France, 2018; pp. $281-286$.

80. Jiang, Z.; Jing, G.; Lijiao, X. Analysis on the Competitiveness of High-End Agricultural Industry in Beijing by Diamond Model. In Proceedings of the Information Science and Management Engineering III, Wuhan, China, 7-8 October 2015; SCITEPRESS Science and Technology Publications: Sanya, China, 2015; pp. 36-41.

81. Khaengkhan, M.; Hotrawisaya, C.; Kiranantawat, B.; Shaharudin, M.R. Comparative Analysis of Multiple Criteria Decision Making (MCDM) Approach in Warehouse Location Selection of Agricultural Products in Thailand. Int. J. Supply Chain. Manag. 2019, 8, 168-175.

82. Toming, K. The Impact of EU Accession on the Export Competitiveness of the Estonian Food Processing Industry. Post-Communist Econ. 2007, 19, 187-207. [CrossRef]

83. Berti, G.; Mulligan, C. Competitiveness of Small Farms and Innovative Food Supply Chains: The Role of Food Hubs in Creating Sustainable Regional and Local Food Systems. Sustainability 2016, 8, 616. [CrossRef]

84. Kherbach, O.; Mocan, M.L. The Importance of Logistics and Supply Chain Management in the Enhancement of Romanian SMEs. Procedia Soc. Behav. Sci. 2016, 221, 405-413. [CrossRef]

85. Herciu, M. Measuring International Competitiveness of Romania by Using Porter's Diamond and Revealed Comparative Advantage. Procedia Econ. Finance 2013, 6, 273-279. [CrossRef] 
86. Bojnec, Š.; Fertő, I. Agro-food trade competitiveness of Central European and Balkan countries. Food Policy 2009, 34, 417-425. [CrossRef]

87. Bojnec, Š.; Fertő, I. Complementarities of trade advantage and trade competitiveness measures. Appl. Econ. 2012, 44, 399-408. [CrossRef]

88. Smith, V.H.; Glauber, J.W. Trade, policy, and food security. Agric. Econ. 2020, 51, 159-171. [CrossRef]

89. Puma, M.J. Resilience of the global food system. Nat. Sustain. 2019, 2, 260-261. [CrossRef]

90. Bojnec, Š.; Fertő, I. Determinants of agro-food trade competition of Central European countries with the European Union. China Econ. Rev. 2009, 20, 327-337. [CrossRef]

91. Christiaensen, L.; Rutledge, Z.; Taylor, J.E. Viewpoint: The future of work in agri-food. Food Policy 2020, 99, 101963. [CrossRef]

92. Rugman, A.M.; Verbeke, A. How to operationalize porter's diamond of international competitiveness. Int. Exec. 1993, 35, $283-299$. [CrossRef]

93. Balassa, B. Trade Liberalisation and "Revealed" Comparative Advantage. Manch. Sch. 1965, 33, 99-123. [CrossRef]

94. Council Regulation (EEC) No 2658/87 of 23 July 1987 on the Tariff and Statistical Nomenclature and on the Common Customs Tariff; Council of the European Union: Brussels, Belgium, 1987.

95. Ianoş, I.; Sorensen, A.; Merciu, C. Incoherence of urban planning policy in Bucharest: Its potential for land use conflict. Land Use Policy 2017, 60, 101-112. [CrossRef]

96. Ion, R.A.; Popescu, C.G. Income Influence on Diet and Health. Qual. Access Success 2018, 19, 254-259.

97. Török, I. Competitiveness of Romanian Regions in the Spatial Structure of the EU. IOP Conf. Series Earth Environ. Sci. 2017, 95, 52013. [CrossRef]

98. Neagu, O.; Neagu, M.-I. Regional Specialisation and Economic Concentration in Romania. Stud. Univ. "Vasile Goldis" Arad Econ. Ser. 2016, 26, 1-17. [CrossRef]

99. Constantin, M.; Strat, G.; Deaconu, M.E.; Pătărlăgeanu, S.R. Innovative Agri-Food Value Chain Management Through a Unique Urban Ecosystem. Manag. Res. Pract. 2021, 13, 5-22. Available online: https://www.researchgate.net/publication/354161934_ Innovative_Agri-food_Value_Chain_Management_Through_a_Unique_Urban_Ecosystem (accessed on 1 December 2021).

100. Grădinaru, S.R.; Triboi, R.; Iojă, C.I.; Artmann, M. Contribution of agricultural activities to urban sustainability: Insights from pastoral practices in Bucharest and its peri-urban area. Habitat Int. 2018, 82, 62-71. [CrossRef]

101. A Petrovici, D.; Ritson, C. Factors influencing consumer dietary health preventative behaviours. BMC Public Health $2006,6,222$. [CrossRef] [PubMed]

102. Alexandri, C.; Luca, L. Food and Nutrition Security in Romania in the Post-Accession Period. Food Nutr. 2016, $16,11-18$.

103. Buliga-Stefanescu, A. Realities and Perspectives on the Mechanization of Romanian Agriculture. Res. J. Agric. Sci. 2019, 51, 39-48.

104. Agarwal, B.; Dobay, K.M.; Sabates-Wheeler, R. Revisiting group farming in a post-socialist economy: The case of Romania. J. Rural Stud. 2020, 81, 148-158. [CrossRef]

105. Burja, V.; Tamas-Szora, A.; Dobra, I.B. Land Concentration, Land Grabbing and Sustainable Development of Agriculture in Romania. Sustainability 2020, 12, 2137. [CrossRef]

106. Alexandri, C.; Luca, L.; Kevorchian, C. Subsistence Economy and Food Security-The Case of Rural Households from Romania. Procedia Econ. Financ. 2015, 22, 672-680. [CrossRef]

107. Alexandri, C. Agricultural Price Volatility_Effects on Food Security. Lucr. Sci. Manag. Agric. 2016, 18, 5.

108. Vasile, A.J.; Andreea, I.R.; Popescu, G.H.; Elvira, N.; Marian, Z. Implications of agricultural bioenergy crop production and prices in changing the land use paradigm-The case of Romania. Land Use Policy 2016, 50, 399-407. [CrossRef]

109. Alboiu, C. Romanian Vegetable Volatility and Comparisons with Other EU Countries. Lucr. Sci. Manag. Agric. $2016,18,5$.

110. Florea, N.V.; Duică, M.C.; Ionescu, C.A.; Duică, A.; Ibinceanu, M.C.O.; Stanescu, S.G. An Analysis of the Influencing Factors of the Romanian Agricultural Output within the Context of Green Economy. Sustainability 2021, 13, 9649. [CrossRef]

111. Levshin, A.; Ivashova, O.; Gasparyan, I.; Gasparyan, S.; Deniskina, N. Competitiveness of Early Potato Production in Two-Crop Culture. In Advances in Economics, Business and Management Research. Proceedings of the International Conference on Policies and Economics Measures for Agricultural Development, Voronezh, Russia, 25-26 May 2020; Atlantis Press: Paris, France, 2020 ; pp. 208-212. [CrossRef]

112. Vlad, I.-M.; Beciu, S.; Ladaru, G.-R. Seasonality and Forecasting in the Romanian Trade with Live Animals. Agric. Agric. Sci. Procedia 2015, 6, 712-719. [CrossRef]

113. Hoehn, D.; Margallo, M.; Laso, J.; Ruiz-Salmón, I.; Batlle-Bayer, L.; Bala, A.; Fullana-I-Palmer, P.; Aldaco, R. A Novel Composite Index for the Development of Decentralized Food Production, Food Loss, and Waste Management Policies: A Water-Climate-Food Nexus Approach. Sustainability 2021, 13, 2839. [CrossRef]

114. Rahoveanu, A.T.; Zugravu, A.G.; Soare, I.; Hassan, A.A.M.; Saleh, K.M. Rural Development-Necessity for Reducing Regional Gaps in Romania. In Proceedings of the International Conference "Risk in Contemporary Economy", Galati, Romania, 19 March-20 May 2016; Editura Universități “Dunărea de Jos”: Galați, Romania, 2016; pp. 564-569.

115. Borychowski, M.; Stępień, S.; Polcyn, J.; Tošović-Stevanović, A.; Ćalović, D.; Lalić, G.; Žuža, M. Socio-Economic Determinants of Small Family Farms' Resilience in Selected Central and Eastern European Countries. Sustainability 2020, 12, 10362. [CrossRef]

116. Fraser, E.D.; Stringer, L.C. Explaining agricultural collapse: Macro-forces, micro-crises and the emergence of land use vulnerability in southern Romania. Glob. Environ. Chang. 2009, 19, 45-53. [CrossRef] 
117. Torky, M.; Hassanein, A.E. Integrating blockchain and the internet of things in precision agriculture: Analysis, opportunities, and challenges. Comput. Electron. Agric. 2020, 178, 105476. [CrossRef]

118. Boboc, D.; Popescu, G.; Stoian, M.; Lădaru, G.-R.; Petrache, D.C. Best Practices for Integrating the Romanian Small Farmers into the Agri-Food Chain. Amfiteatru Econ. 2017, 19, 315-326.

119. Henson, S.; Humphrey, J. Understanding the Complexities of Private Standards in Global Agri-Food Chains as They Impact Developing Countries. J. Dev. Stud. 2010, 46, 1628-1646. [CrossRef] [PubMed]

120. Jha, K.; Doshi, A.; Patel, P.; Shah, M. A comprehensive review on automation in agriculture using artificial intelligence. Artif. Intell. Agric. 2019, 2, 1-12. [CrossRef] 